\title{
A PERCEPÇÃO SOBRE ÉTICA DE ESTUDANTES DE CURSO DE GRADUAÇÃO EM CIÊNCIAS CONTÁBEIS
}

\section{THE ETHICS PERCEPTION OF UNDEGRADUATE ACCOUNTING STUDENTS}

\section{LA PERCEPCIÓN SOBRE ÉTICA DE ESTUDIANTES DE CURSO DE GRADUACIÓN EN CIENCIAS CONTABLES}

\author{
ANDRÉIA CIRYNO DE FREITAS \\ Bacharel em Ciências Contábeis (Unisinos). Bacharel em Filosofia (Unisinos) \\ andrici@hotmail.com
}

\section{CARLOS ALBERTO DIEHL}

Doutor em Engenharia de Produção UFSC / HEC (Montreal)

Professor Titular do Programa de Pós-graduação em Ciências Contábeis da Unisinos cd@unisinos.br

\section{CLEA BEATRIZ MACAGNAN}

Doutora em Creación, Estratégia e Gestión de Empresas

(Universidad Autonoma de Barcelona)

Coordenadora do Programa de Pós-graduação em Ciências Contábeis da Unisinos clea@unisinos.br

\section{RESUMO}

A sociedade atual passa por uma crise moral que é diariamente noticiada pelos meios de comunicação sob a forma de violência, corrupção e fraudes, entre outros. Nesse contexto, o uso da palavra moral tem sido trivial, muitas vezes com certa debilidade se- 
mântica. É necessário, então, reabilitar o exato sentido do termo, bem como seu estudo, objeto de interesse da ética. Assim, o objetivo desse artigo é traçar a percepção sobre o perfil prático moral e teórico moral de contabilistas em processo de formação. Para tanto, é realizada uma pesquisa quantitativa com graduandos de Contabilidade em uma IES por meio de questionários fechados, com 232 alunos, sob a ótica da ética kantiana. Os resultados indicam que os alunos têm julgamento moral condizente com o perfil esperado de futuros profissionais, sendo o aprendizado maior para aqueles mais próximos do final do curso. No entanto, apresentam lacunas em sua formação, ao não entenderem claramente o conceito de ética, bem como não conhecerem o Código de Ética Profissional do Contabilista, embora o julguem importante. Os resultados indicam uma tendência a agir de acordo com inclinações, ferindo o princípio do imperativo categórico de Kant.

Palavras-chave: Ética Profissional; Formação Profissional; Contabilista; Kant.

\section{ABSTRACT}

Today's society is undergoing a moral crisis that is reported daily by the media in the form of violence, corruption and fraud, among others. In this context, the use of the word moral has been trivial, often with some weak semantics. It is therefore necessary to rehabilitate the exact meaning of the term, as well as its study, that is object of interest of ethics. Thus, the aim was to map the perception of practical and theoretical moral profile of accountants in moral education process. Thereunto, was carried out a quantitative research with accounting undergraduates in a higher education institution through questionnaires, with 232 students, from the perspective of Kantian ethics. The results indicate that students have moral judgments consistent with the expected pattern of future professionals. Those nearer the end of the course show higher learning. However, they show gaps in their education, by not understanding clearly the concept of ethics as well as not knowing the Code of Professional Ethics of Accounting, although they consider it important. The results indicate a tendency to act in accordance with inclinations, injuring the principle of Kant's categorical imperative.

Key words: Professional Ethics; Professional Education; Accountant; Kant.

\section{RESUMEN}

La sociedad actual pasa por una crisis moral que es diariamente noticiada por los medios de comunicación bajo la forma de violencia, corrupción y fraudes, entre otros. En ese contexto, el uso de la palabra moral ha sido trivial, muchas veces con cierta debilidad semántica. Es necesario, entonces, rehabilitar el exacto sentido del término, así como su 
estudio, objeto de interés de la ética. Así, el objetivo de ese artículo es trazar la percepción sobre el perfil práctico moral y teórico moral de contabilistas en proceso de formación. Para tanto, es realizada una pesquisa cuantitativa con graduandos de contabilidad en una IES por medio de cuestionarios cerrados, con 232 alumnos, bajo la óptica de la ética kantiana. Los resultados indican que los alumnos tienen juzgamiento moral adecuado con el perfil esperado de futuros profesionales, siendo el aprendizaje mayor para aquellos más próximos del final del curso. No obstante, presentan lagunas en su formación, al no entender claramente el concepto de ética, así como no conocer el Código de Ética Profesional del Contabilista, aunque lo juzguen importante. Los resultados indican una tendencia a actuar de acuerdo con inclinaciones, hiriendo el principio del imperativo categórico de Kant.

Palabras clave: Ética Profesional; Formación Profesional; Contabilista; Kant.

\section{INTRODUÇÃO}

Existe certa debilidade semântica no uso da palavra "ética", que poderia ser causada pelo emprego constante e trivial do termo. No entanto, poder-se-ia dizer que nunca foi tão necessário reabilitar este conceito, pois a violência e o egoísmo são reflexos de uma crise moral que atinge a sociedade (NALINI, 1999). Em sociedades democráticas, essa crise moral é veiculada com frequência pelos meios de comunicação social. A televisão, o rádio e o jornal relatam casos de corrupção na política, fraudes nas empresas, violência doméstica, roubos, assaltos, sequestros, etc. Não é possível negar: é neste contexto social que se trabalha, que se cresce e que se vive.

As questões de ordem moral apresentam-se a todos os seres humanos; são problemas práticos dos quais ninguém pode eximir-se e cujo início remete a origem do ser como ser social (VASQUEZ, 1989). Poderia dizer que tais problemas seriam de ordem individual, social ou profissional. O presente artigo ocupa-se dos problemas práticos morais e teóricos morais, de caráter profissional, em particular aqueles concernentes à profissão de contabilista.

As reflexões apresentadas neste artigo remetem à forma de agir e pensar em situações específicas que envolvem problemas morais de caráter profissional. Assim, a questão de pesquisa é: qual a percepção sobre ética da categoria de profissionais, em processo de formação em uma Instituição de Ensino Superior (IES)? Em outras palavras, neste artigo será apresentada a percepção do perfil prático-moral e teórico-moral, resultado de uma pesquisa desenvolvida com futuros profissionais da Contabilidade.

A ética tem um papel muito importante a desempenhar na Contabilidade e há necessidade de ampliação de pesquisa nessa área (HENDRIKSEN e VAN BREDA, 1999). Ainda, poucos estudos foram desenvolvidos sobre o tema, principalmente sob o enfoque adotado, a ética kantiana.

Este artigo contribui para o avanço do conhecimento acerca do assunto, à medida que, ao constatar o perfil prático moral e teórico moral do futuro profissional, se poderia 
atuar de forma preventiva com o objetivo de intensificar a formação ética e evitar possíveis processos judiciais. Poder-se-ia adequar os currículos escolares com o objetivo de suprir as deficiências constatadas e incentivar os órgãos de classe a promover eventos formativos direcionados a sanar as carências encontradas. Com isso, os profissionais da área estariam preparados para assumir os desafios que a profissão oferece. O esclarecimento, a informação e a orientação auxiliam o profissional a discernir entre as diversas situações de conflito ético, para que sua atuação profissional seja honrosa e honesta.

$\mathrm{O}$ artigo está organizado em cinco seções. A primeira abrange a introdução, para, no segundo, ser apresentado o referencial teórico, subdividido em quatro partes: (1) referências aos fundamentos de ética geral; (2) alguns elementos da ética kantiana; (3) noções teóricas de Contabilidade; e (4) considerações acerca da ética profissional. A terceira seção é composta pela metodologia, em que se delineia a pesquisa empírica, com a apresentação da população e da amostra, a descrição da fonte e da coleta das evidências e a escolha da técnica de análise. A quarta seção contém a análise dos resultados, configurado em duas partes: (1) análise do perfil prático moral e (2) análise do perfil teórico-moral. Têm-se, por fim, as considerações finais e as recomendações, seguidas pelas referências bibliográficas.

\section{REFERENCIAL TEÓRICO}

Esta seção objetiva apresentar a revisão de literatura que fundamenta este artigo e subdivide-se em quatro partes: (1) aspectos gerais sobre ética geral; (2) elementos de ética kantiana; (3) noções teóricas da Contabilidade; e (4) considerações acerca da ética profissional.

\subsection{Fundamentos de Ética Geral}

A presente seção traz algumas ideias acerca da origem da moral, da característica de mutabilidade do comportamento moral e do conceito de ética e da obrigatoriedade moral.

\subsubsection{A natureza social do ser humano como origem da moral}

A moral nasceu porque o homem precisou associar-se para se fortalecer e garantir a própria subsistência e a afirmação da tribo ou gen. A fragilidade humana determina que, para enfrentar um mundo hostil, é necessário reunir forças para multiplicar o seu poder. Surge, assim, a necessidade de normas e prescrições que visam assegurar a concordância do comportamento de cada indivíduo com os interesses da coletividade (VASQUEZ, 1989).

Não é possível negar a natureza social do ser humano, dado que ele já nasce pertencendo a um grupo. Conforme vai crescendo, passa, gradativamente, a participar de outros grupos. Portanto, são nos grupos sociais onde ocorre o intercâmbio de conhecimentos, hábitos e costumes, fatores que contribuem para o seu crescimento moral (FORTES, 2005). 
A convivência em sociedade faz com que as pessoas estabeleçam relacionamentos, os quais manifestam as crenças e os valores individuais. Essas diferenças, individuais ou do grupo social, provocam conflitos. Para que seja possível, então, uma convivência pacífica no âmbito de cada sociedade, ou entre sociedades distintas, faz-se necessário que cada pessoa, dentro dos limites de suas crenças e valores, adote comportamentos que respeitem e preservem os direitos de seus semelhantes (LISBOA, 1997). Assim, como afirma Cortina, tan imposible es que existan sociedades sin valores morales como existan personas amorales, situadas más allá del bien y del mal (1998, p. 112).

\subsubsection{A mutabilidade do comportamento moral}

Algumas mudanças histórico-sociais, como o aumento da produtividade (criação de gado e agricultura) e o surgimento de novas forças de trabalho (escravos) deram origem à desigualdade entre as famílias da tribo. Dessa forma, ocorre o nascimento da propriedade privada e a divisão da sociedade em classes, que permitiram o aparecimento de novas formas de moral (VASQUEZ, 1989).

O comportamento moral varia com o tempo e o lugar, de acordo com as mudanças ocorridas na organização das formas efetivas de trabalho. Toda vez que as relações de produção são modificadas, as normas de comportamento coletivo também sofrem alteração. Isso ocorreu, por exemplo, na passagem do regime feudal para a moral cavalheiresca e desta para a moral burguesa (ARANHA e MARTINS, 1993).

Ao longo da história, o comportamento humano igualmente tem passado por mudanças incessantes. Tais mudanças estão vinculadas ao processo de evolução dos indivíduos e da sociedade. Determinados comportamentos que antes eram impróprios, agora já não têm reprovação social (FORTES, 2005).

\subsubsection{O conceito de ética e a obrigação moral}

Cortina define

la moral se refiere a La 'libertad interna', sea de las personas, sea de las organizaciones, a sus convicciones y hábitos, a sus orientaciones y a las normas que ellas entienden como suyas". Ahora, "el derecho, por su parte, se refiere a la 'libertad externa', a las relaciones entre personas y las organizaciones, reguladas por una autoridad externa a ellas, con capacidad sancionadora, aun en el caso de las sociedades democráticas (1998, p. 110).

A ética também é reconhecida como uma filosofia prática cujo conteúdo é o agir humano. Nessa perspectiva, defini-la como ciência seria restringir a amplitude das discussões 
que contempla, pois seu conteúdo é ilimitado, uma vez que as ações humanas também o são (BITTAR, 2007). Em outra perspectiva, como a de Vasquez (1989), a ética seria a ciência do comportamento humano em sociedade, ou seja, apresenta caráter científico. Como ciência, ela tem um objeto próprio: o agir moral humano. Embora parta de evidências empíricas, a ética não permanece na simples descrição dos fatos, mas elabora conceitos e teorias. Por isso suas proposições devem ter rigor, coerência e fundamentação, como acontece com as proposições científicas.

O comportamento moral é obrigatório e devido. A obrigatoriedade supõe, necessariamente, a liberdade de ação do sujeito, pois, sem a liberdade, o ato moral não existiria. As teorias da obrigação moral podem ser divididas em dois gêneros: as deontológicas (grego deón $=$ dever) e as teleológicas (grego télos = fim). Para as deontológicas, a obrigação moral não depende das consequências do ato moral, ou de uma norma geral. Já para as teleológicas, a obrigação moral depende unicamente das consequências, isto é, do benefício que podem, ou não, trazer (VASQUEZ, 1989).

\subsection{Elementos da Ética Kantiana}

A presente seção trata da ética kantiana. Immanuel Kant foi um filósofo do século XVIII, um dos maiores expoentes da teoria deontológica da moral. Aborda-se, resumidamente, nesta seção o conceito de sujeito e vontade, de dever e obrigação e, por fim, dos imperativos.

\subsubsection{O sujeito e a vontade}

Para Kant (1980), o ser humano sabe-se pertencente, simultaneamente, ao mundo sensível e ao mundo inteligível, e da consciência dessa dupla surge a obrigação moral. Se pertencesse apenas ao mundo sensível, as suas ações seriam todas conforme a lei natural das inclinações e não existiria ação moral. Da mesma forma, se pertencesse somente ao mundo inteligível, todo o seu proceder seria de acordo com o princípio da autonomia e da liberdade (independência do sujeito de tudo o que é empírico, sensível, finito e contingente), mas também aqui não haveria ação moral e, sim, o cumprimento de uma predisposição.

Quando Kant aborda a fundamentação da metafísica dos costumes, desenvolve um discurso antropológico, com o propósito de demonstrar que todos os atributos humanos são vulneráveis se não existir um princípio que lhes sirva de sustentação, princípio que ele intitula de "boa vontade" (goodwill). A boa vontade não está sujeita a interferências, sejam elas negativas (corruptíveis - subtrair algo) ou positivas (atributivas - acrescentar algo). A boa vontade, sob este aspecto, é estática, completa, una.

\subsubsection{O dever e a obrigação}

Kant passa a utilizar o conceito de dever, que "contém em si o de boa vontade" (KANT, 1980, p.112), com o propósito de desvencilhar o dever da inclinação (sentimento), eviden- 
ciando como a razão ordena independentemente de móbiles. O dever é entendido como necessidade de ação por respeito à lei. Para ele, a obrigação surge porque o sujeito possui uma capacidade de querer, uma vontade que nem sempre coincide com a razão. Por isso a submissão da vontade à razão constitui-se em obrigação para esse ser, cuja finalidade não é buscar a própria felicidade. Disso provém que a ação possui conteúdo moral se, e somente se, for praticada por obrigação, em oposição às inclinações ou intenções egoístas.

\subsubsection{Os imperativos}

Na perspectiva kantiana, o agir do ser racional é o único que pode se dar pela representação das leis, isto é, princípios que podem ser subjetivos ou objetivos. Os subjetivos são máximas válidas apenas para o sujeito, enquanto os objetivos possuem a característica de leis e são válidos para todo o ser racional (KANT,1980).

Para esse ponto de vista, os imperativos podem ser subdivididos em hipotético ou categórico. Os primeiros referem-se àquelas ações que servem de meio para uma finalidade, enquanto o segundo consiste em ser uma ação fim em si mesma. O imperativo categórico é formal, ordena apenas agir conforme a lei que o constitui; não fornece nenhum conteúdo ou matéria como acontece com o hipotético; seria o imperativo da moralidade.

Do imperativo categórico resulta o dever que forçam o sujeito a viver segundo um mundo racional inteligível, onde ele está livre de qualquer dado empírico e contingente. Esse imperativo é conhecido pela sentença: aja de tal forma que sua máxima possa tornarse uma lei universal (KANT, 1938).

\subsection{Noções teóricas de Contabilidade}

A presente seção apresenta ideias acerca da Contabilidade. Faz-se um breve relato da história da Contabilidade e a da história da educação contábil no Brasil, destacando as principais áreas de atuação do profissional da Contabilidade.

\subsubsection{A ciência da Contabilidade e a teoria da Contabilidade}

Sá (2008) entende que a Contabilidade é uma ciência porque possui todos os requisitos necessários para ser assim qualificada. Esses requisitos são: objeto, finalidade, método, tradição, utilidade, teorias próprias, doutrinas científicas, correlação como outras doutrinas, enunciar verdades universais, permitir previsões, permitir levantamento de hipóteses, ter caráter analítico. ludícibus et al. (2006) compreendem que a Contabilidade pode ser classificada como ciência social no que se refere à sua finalidade, uma vez que permite aos usuários das informações ter um conhecimento aprimorado das características de determinada entidade, o que contribui no processo de tomada de decisões.

Quanto à teoria da Contabilidade, Hendriksen e Van Breda (1999) entendem que as questões teóricas não são apenas teóricas, elas são ao mesmo tempo questões práticas, 
uma vez que a interpretação teórica pode ter relevância prática. A interpretação da teoria da Contabilidade não é feita apenas pelos órgãos normativos, ainda porque dificilmente uma questão pode ser totalmente dirimida. Por isso as questões teóricas devem ser analisadas também em nível local e cabe ao contador, portanto, exercer sua capacidade de julgamento em cada caso.

\subsubsection{A história da Contabilidade e a história da educação contábil no Brasil}

Há provas arqueológicas do período conhecido como paleolítico superior (entre 10.000 a 20.000 anos atrás) que demonstram manifestações humanas inteligentes. Esses registros comprovam a incidência de noções de qualidade e quantidade de objetos, de forma que é possível afirmar que a Contabilidade nasceu com os primórdios da civilização (SÁ, 2008).

O pensamento contábil evoluiu ao longo do tempo, sendo possível demarcar cada fase do progresso desse conhecimento. O autor entende que a Contabilidade, como ciência social, está ligada aos interesses humanos, pois cuida da riqueza, entendida como geração de meios destinados à satisfação das necessidades do organismo social (SÁ, 1997). Seria reconhecido o processo evolutivo da Contabilidade, por suas escolas: contista, personalista, neocontista, entre outras, que fundamentam as teorias e as práticas contábeis (SCHIMIDT, 2000).

A Contabilidade teria surgido da junção de vários elementos: o desenvolvimento da escrita e da aritmética, a expansão do uso da moeda, a instituição da propriedade privada e a acumulação do capital. Esses eventos contribuíram para que o conhecimento acumulado desde as primeiras civilizações (Mesopotâmia, Egito, Índia, Oriente Médio) convergissem em sistemas de escrituração, por meio da utilização das partidas dobradas, tendo como marco o livro escrito pelo frei Luca Pacioli (aproximadamente século XIV) (HENDRIKSEN E VAN BREDA, 1999). A evolução da Contabilidade está ligada ao progresso da humanidade (PELEIAS et al., 2007). No Brasil não foi diferente, pois a Contabilidade e o próprio ensino desta disciplina também foram marcados por eventos econômicos, políticos e sociais, conforme a seguir discutido.

\subsubsection{A atuação do profissional contábil}

Fortes (2005) apresenta duas categorias profissionais previstas pelo Decreto-Lei $n .{ }^{\circ}$ 9.295/46, a saber: (1) a do contador e (2) a do técnico em contabilidade. O contador é o profissional que possui curso superior de Bacharel em Ciências Contábeis e possui registro no CRC. O técnico é profissional que possui curso médio, em nível de segundo grau, e que também está registrado no CRC.

As atividades do contador (nível superior) podem ocorrer de diversas formas, entre elas: atuação nas esferas pública e privada; a prática da perícia; as atividades de auditoria; de controladoria; e ensino. Em qualquer campo em que esteja atuando, depara-se com a 
informação que é vista como um bem valioso para a economia e este simples fato demonstra que no exercício profissional os valores éticos do contabilista, em qualquer nível, são constantemente postos à prova (LISBOA, 1997).

O comportamento ético do contabilista pode ser um fator decisivo do seu sucesso ou fracasso profissional, independente do setor onde esteja atuando (LISBOA, 1997). Convém ressaltar que essas considerações são válidas para qualquer profissional. Tanto o contador quanto o advogado, o administrador, etc., deveriam ter uma conduta ética adequada e condizente com o ministério que exercem.

\subsection{Considerações de ética profissional}

O profissional, em suas diferentes possibilidades, exerce um tipo de atividade social. Caracteriza-se por prestar um serviço específico, adota atitudes determinadas pelo seu exercício, com interesse peculiar que a atividade persegue e compromete-se a perseguir as metas desta atividade social (CORTINA, 1998). Essas características manifestam-se no comportamento fundamentado pela ética da profissão.

Na sequência abordar-se-á o conceito geral de ética profissional e faz considerações sobre os códigos de ética profissional. Aborda-se, especificamente, a ética do profissional da Contabilidade, trazendo informações acerca da ocorrência de infrações e de fraudes contábeis e dos processos de fiscalização.

\subsubsection{A ética e o código de ética profissional}

A ética profissional é a aplicação da ética geral nas atividades profissionais (CAMARGO,1999). Compreende-se que a ética profissional é decorrência da natureza humana, da moral como princípio que rege as relações interpessoais e disto provém que as atividades profissionais tenham igualmente esta característica.

A formação ética profissional impõe-se por duas razões fundamentais: (1) porque os conhecimentos técnico-científicos não seriam suficientes para o exercício profissional, pois todo conhecimento tem que estar a serviço de um ideal, de uma razão de ser e; (2) porque todo saber humano já supõe dois elementos fundamentais: o conhecimento e o valor (MOTTA, 1984).

Quando se trata de ética profissional, aborda-se também o código de ética das diversas categorias. Para Lisboa (1997), um dos objetivos da existência de um código de ética é auxiliar na formação ética, na constituição de uma consciência sobre regras e padrões de conduta.

\subsubsection{A ética do profissional da Contabilidade}

A escolha de uma profissão traz consigo o dever do conhecimento e este implica o dever da execução adequada da referida atividade. O profissional da Contabilidade possui deveres para com as instituições, assim como ao ensino, a pesquisa, a difusão cultural 
e educacional, ao mercado e a sociedade (SÁ, 2000). Nessa condição, é essencial para o profissional da Contabilidade a adesão ao conjunto de princípios éticos que sirvam de premissas para as respectivas ações. O profissional, por sua vez, deveria defender abertamente esses princípios e valores, ainda porque trabalha diariamente com aquilo que é hoje considerado um dos bens mais preciosos da economia: a informação (LISBOA, 1997).

Um dos principais aspectos a serem observados pelos profissionais da Contabilidade é o sigilo das informações a que tem acesso. O sigilo constitui-se em dever ético e impede o profissional de revelar dados confidenciais que somente tem acesso pela atividade que exerce. Além do sigilo, o profissional contábil deveria agir sempre com honestidade e dignidade, segundo orienta a ética. Tais atitudes seriam um diferencial para contador e lhe confere autoridade moral, elemento fundamental nas relações profissionais (FORTES, 2005).

Convém mencionar que a Resolução Conselho Federal de Contabilidade (CFC) 803/96 aprova o código de Ética Profissional do Contabilista e apresenta no Capítulo II, art. $2^{\circ}$, os deveres que devem ser observados no exercício profissional. A mesma Resolução apresenta no Capítulo II, parágrafo $3^{\circ}$, as atitudes e ações que são vedadas ao profissional da Contabilidade.

\subsubsection{As infrações e fraudes contábeis e os processos de fiscalização}

Fraude pode ser definida como erro intencional, cuja finalidade é prejudicar alguém. Um bom controle interno tende a tornar mais difícil a prática de fraudes. Elas poderiam ocorrer com o uso de cheques, extratos de contas, mercadorias, diários, razões, livros auxiliares, demonstrações contábeis, declarações, etc. (SÁ, 1982) e "Con lo cual pierde su auténtico sentido y su legitimidad social” (CORTINA, 1998, p. 152).

Fortes (2005), tratando da ética do profissional da Contabilidade, é categórico ao dizer que as normas existem para serem cumpridas e aqueles que não as cumprirem poderão sofrer as penalidades. Tais penas estão previstas na Resolução CFC n. ${ }^{\circ}$ 949/02, que traz o Regulamento de Procedimentos Processuais dos Conselhos de Contabilidade, no Capítulo X, art. 58. O autor também referencia a Resolução CFC n. ${ }^{\circ}$ 960/03, que estabelece o Regulamento Geral dos Conselhos de Contabilidade e cita no Capítulo IV, art. 24, itens que se constituem infrações.

Quando, no exercício profissional, o contabilista viola alguma prescrição, cabe aos Conselhos Regionais de Contabilidade (CRCs) do território da ocorrência da infração instaurar um processo para apurar os fatos (FORTES, 2005). Portanto, são os CRCs os responsáveis pela fiscalização do exercício da profissão contábil. Na página eletrônica do CRC do Rio Grande do Sul, por exemplo, constam informações e dados relativos à fiscalização realizada nos últimos anos: referentes às ações do departamento de fiscalização; relativas às principais infrações incorridas, além de decisões dos processos julgados. 


\section{METODOLOGIA}

Esta seção apresenta a metodologia de pesquisa utilizada para alcançar o objetivo proposto. Traz a definição da população e da amostra analisada, a coleta e análise das evidências.

\subsection{População e amostra analisada}

Segundo a página eletrônica do Ministério da Educação (MEC) / Instituto Nacional de Educação e Pesquisas Educacionais (INEP), atualmente no Brasil existem 2.281 Instituições de Ensino Superior (IES), (conforme Censo da Educação Superior de 2007). Destas, 1.139 IES possuem o curso de Ciências Contábeis. A população estudada caracteriza-se por alunos do curso de graduação em Ciências Contábeis, de uma universidade privada no sul do Brasil. Desse universo, a pesquisa tem como amostra 232 alunos, o que equivale a 38,03\% do total (610) de alunos do curso. O tipo de amostragem utilizada nesta pesquisa é por acessibilidade: os alunos foram convidados a responder ao questionário, sendo preservada a possibilidade de recusa. Obteve-se um total de 67 questionários respondidos por alunos e 165 por alunas, o que equivale respectivamente a 34,9\% (192) e 39,5\% de cada gênero.

\subsection{Coleta de evidências}

Nessa pesquisa, a coleta das evidências ocorreu por meio de um questionário de múltipla escolha aplicado aos alunos no mês de setembro de 2009. Lakatos e Marconi (2008) definem questionário como instrumento de coleta de dados, composto por um conjunto de perguntas ordenadas, as quais devem ser respondidas por escrito. $O$ instrumento de pesquisa foi montado a partir da base teórica utilizada e do Código de Ética Profissional do Contabilista (CEPC) (CFC, 1996).

\subsection{Análise de evidências}

Para analisar as evidências, convencionou-se agrupar os questionários por semestre, sendo: a) $1^{\circ}$ a $3^{\circ}$ semestre - grupo 1 ; b) $4^{\circ}$ a $6^{\circ}$ semestre - grupo 2 ; c) $7^{\circ}$ e $8^{\circ}$. semestre - grupo 3. A análise procurou verificar se existem semelhanças e diferenças entre os resultados encontrados nos grupos de semestres, ou seja, entre o universo pesquisado em início de curso e em final de curso. Dessa forma, é possível avaliar se existe mudança na percepção dos alunos acerca dos conceitos éticos.

A estrutura da análise está composta de duas partes: (1) os aspectos práticos e; (2) os aspectos teóricos. Para cada tópico analisado, apresentam-se os resultados obtidos e a interpretação realizada, levando-se em consideração o referencial teórico utilizado neste estudo. Para análise das evidências, utilizaram-se gráficos, os quais permitem visualizar as diferentes respostas obtidas por semestres, possibilitando estabelecer um comparativo. 


\section{ANÁLISE DOS RESULTADOS}

Esta seção apresenta a análise das evidências e está dividida em 2 partes: na primeira, proporciona a análise do perfil prático moral e, na segunda, traz a análise do perfil teórico moral.

\subsection{Caracterização dos respondentes}

A presente seção se ocupa das questões cujo intuito era conhecer o perfil geral dos alunos no que diz respeito a gênero, idade, semestre e atuação profissional.

\subsubsection{Quanto ao gênero dos alunos da amostra}

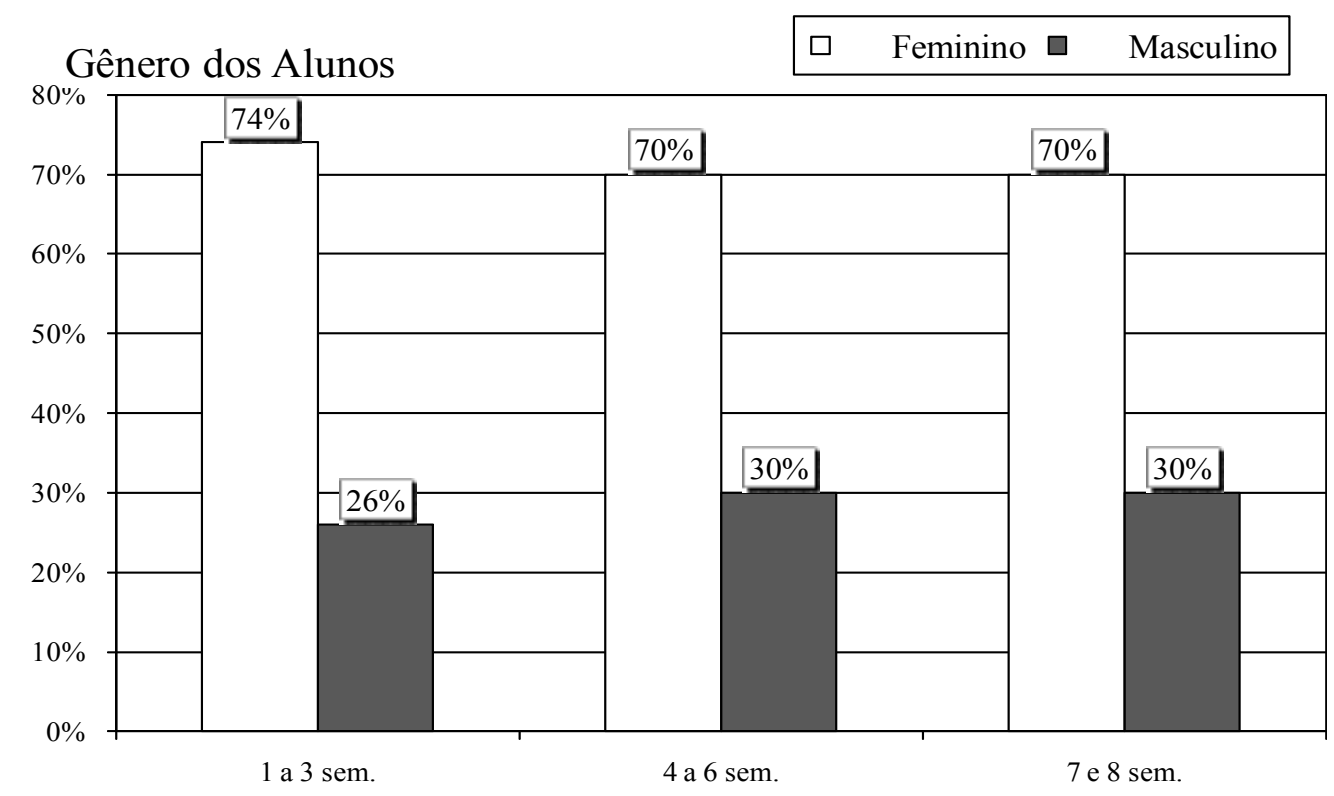

Gráfico 1 - Gênero dos alunos

Fonte: Elaborado pelos autores

Observa-se predominância feminina em todos os semestres, ou seja, o curso de Ciências Contábeis da IES está graduando mais profissionais do sexo feminino do que do sexo masculino (Gráfico 1).

Costa (2007), em pesquisa realizada nas IES do Estado de Santa Catarina, constatou que de 192 egressos 112 eram do sexo feminino, o que demonstra, segundo o autor, significativa mudança cultural, pois as mulheres estão, cada vez mais, se inserindo nesta área que até pouco tempo atrás era de predominância masculina. Isso porque, em geral, os salários são atraentes e as mulheres possuem qualidades como organização e dedicação, características requeridas para o exercício da profissão. $O$ autor, no entanto, adverte que podem existir variações nos diferentes Estados, podendo ser que em outros locais o número de profissionais formados, que são do sexo masculino, seja bem superior ao feminino. 
Convém mencionar que, segundo o site do CRC do Rio grande do Sul, atualmente no estado existem 18.229 profissionais homens e 12.544 profissionais mulheres, ou seja, em âmbito geral, no Estado do Rio Grande do Sul ainda existe preponderância masculina no ramo da Contabilidade.

\subsubsection{Quanto à idade dos alunos da amostra}

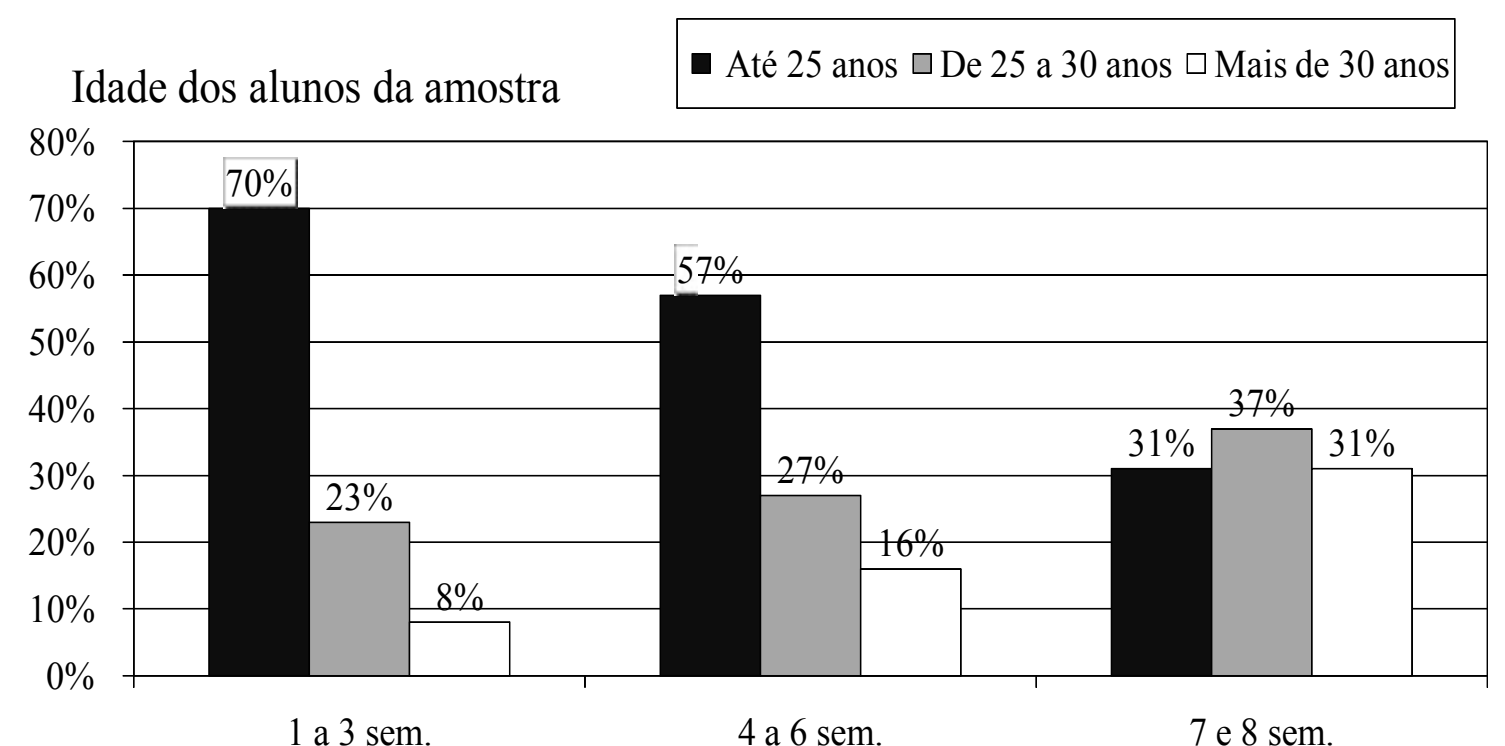

Gráfico 2 - Idade dos alunos

Fonte: Elaborado pelos autores

Constata-se que $70 \%$ dos alunos do grupo 1 e $57 \%$ dos alunos do grupo 2 possuem até 25 anos, enquanto que no grupo 3 apenas $31 \%$ dos alunos pertencem a esta faixa etária (Gráfico 2). A faixa etária predominante do grupo 3 é de alunos que possuem entre 25 e 30 anos, o que equivale a $37 \%$ do total do grupo. Nota-se que no grupo 3 o percentual de alunos que possuem menos de 25 anos decresce e o percentual de alunos que possuem mais de 30 anos cresce, isto é, existe relação crescente entre idade e semestre. Conforme aumenta o semestre, aumenta também a idade dos estudantes, o que pode ser considerado normal e esperado para um curso de graduação de duração de 4 anos.

Como pode ser visualizado pelo gráfico, existe maior semelhança etária entre os alunos de início de curso e maior disparidade etária entre os grupos de alunos de final de curso. Mesmo assim, chama atenção a grande incidência de alunos que possuem até 25 anos, distribuídos entre os diversos semestres. 


\subsubsection{Quanto à atuação profissional dos alunos da amostra - questão 4:}

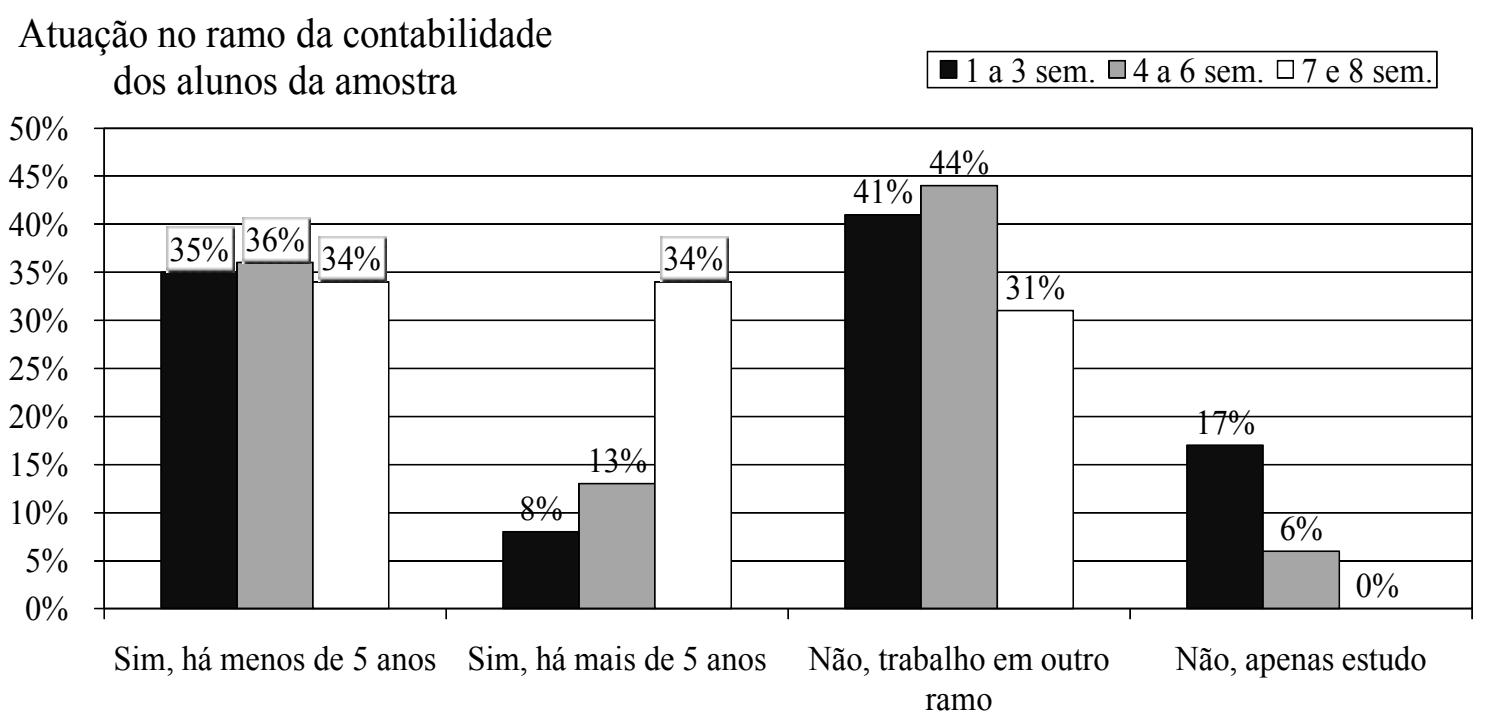

Gráfico 3 - Atuação profissional dos alunos

Fonte: Elaborado pelos autores

Pelo Gráfico 3, pode-se observar que não existe diferença significativa entre os percentuais de alunos de cada grupo que trabalham com Contabilidade há menos de 5 anos. Existe, entretanto, grande variação entre os percentuais dos grupos de alunos que trabaIham com Contabilidade há mais de 5 anos. O percentual de alunos da amostra que atuam no ramo na Contabilidade há mais de 5 anos é de $34 \%$ no grupo 3 , enquanto é de apenas $8 \%$ no grupo 1 , isto é, apresenta variação de $26 \%$. Verifica-se que o índice de alunos que trabalham em outro ramo que não é a Contabilidade é bem maior nos semestres iniciais, sendo de $41 \%$ no grupo 1 e de $44 \%$ no grupo 2 , enquanto é de $31 \%$ no grupo 3 . 0 índice de alunos da amostra que não trabalham e apenas estudam é inexistente entre os alunos em final de curso, enquanto é de $17 \%$ entre os alunos do início de curso, e de $6 \%$ entre os alunos que pertencem ao grupo 2, uma evolução normal.

Convém ressaltar que os alunos do grupo 3 são aqueles que trabalham com Contabilidade há mais tempo (mais de 5 anos); são aqueles que menos exercem funções fora da área contábil (31\%); e são aqueles que na sua totalidade (100\%) trabalham e estudam.

\subsection{Análise do perfil prático moral}

\subsubsection{Quanto às infrações cometidas por profissionais da Contabilidade}

A alternativa afirmativa de que os profissionais cometem infrações por falta de conhecimento obteve: $20 \%$, 26\% e $24 \%$ das respostas dos respectivos grupos (Gráfico 4). Acerca deste tópico, convém ressaltar o entendimento de Bittar (2007) de que existe um 
dever ético de saber, ou seja, é obrigação do profissional ter preparo técnico e intelectual adequado para exercer o mister escolhido.

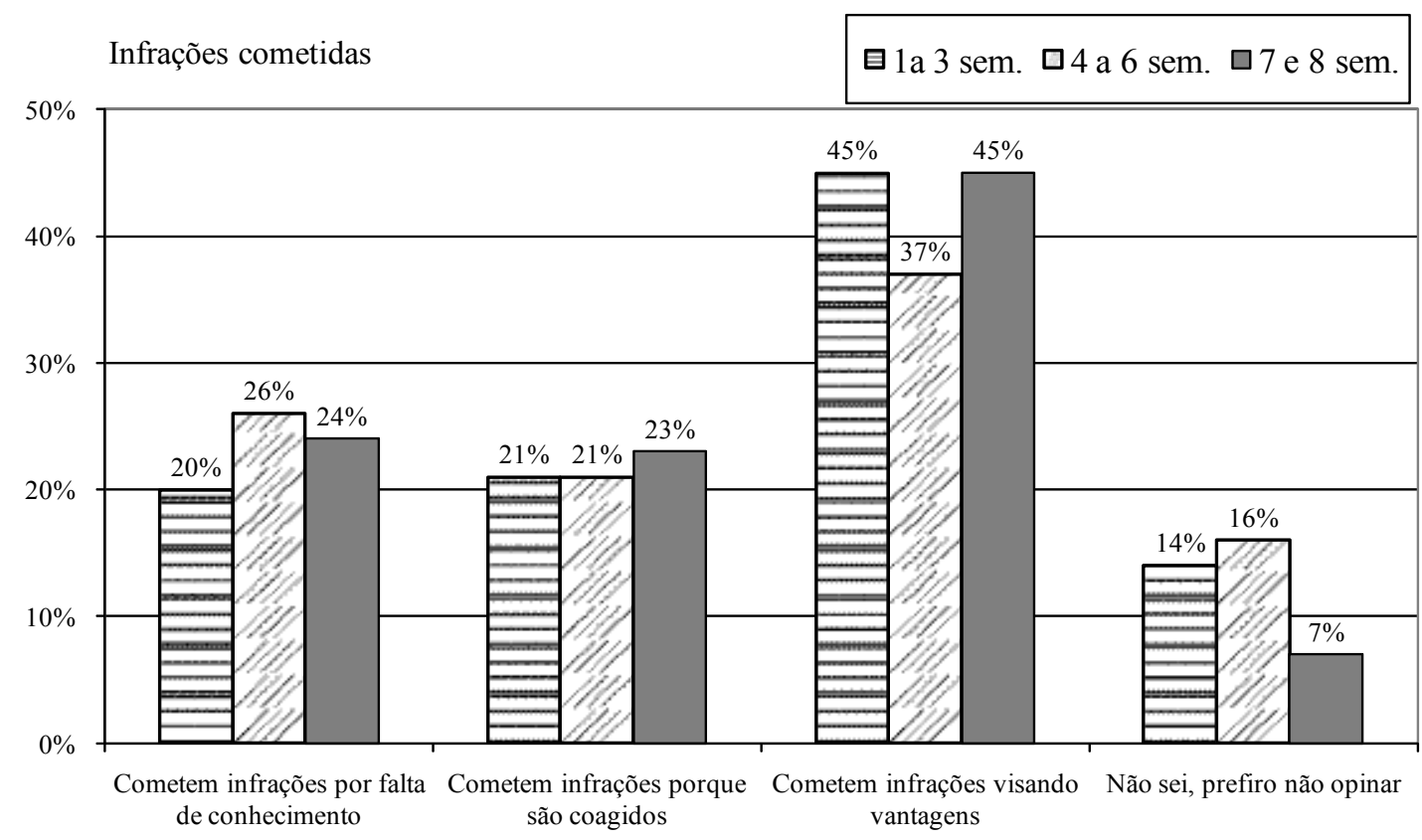

Gráfico 4 - Causas de infrações cometidas

Fonte: Elaborado pelos autores

O item que expõe que os profissionais cometem infrações porque são coagidos apresentou $21 \%$, 21\% e $23 \%$ das respostas dos respectivos grupos. Segundo Vasquez (1989), para que uma pessoa possa ser responsabilizada por seus atos, é necessário que o execute por vontade própria, isto é, que não seja forçada a realizá-lo.

O tópico que menciona que os profissionais cometem infrações visando vantagens recebeu $45 \%, 37 \%$ e $45 \%$ das respostas de cada grupo da amostra. Pode-se dizer, de acordo com a teoria moral kantiana (1980), que, para parcela considerável de cada grupo, os profissionais da Contabilidade não exercem sua liberdade e se deixam levar pelas inclinações (o que se justifica pela escolha desta alternativa).

\subsubsection{Quanto à ocorrência de fraudes contábeis}

Como podem ser visualizados no Gráfico 5, os grupos dividem-se entre o item que diz que as fraudes ocorrem porque falta controle interno (39\%, 45\% e 48\%) e entre a alternativa que diz que as fraudes ocorrem porque os profissionais são desonestos $(40 \%, 38 \%$ e $42 \%$ ). Nota-se que poucos atribuem a ocorrência de fraudes ao item porque os profissionais são mal remunerados ( $9 \%, 8 \%$ e $5 \%)$. Segundo a compreensão de parte considerável da população analisada, para se diminuir a incidência de infrações, é preciso aumentar o controle interno, ou seja, devem-se aumentar os mecanismos de fiscalização. Este posi- 
cionamento converge com o entendimento de Sá (1982), segundo o qual a maioria das fraudes ocorre por falha no controle interno.

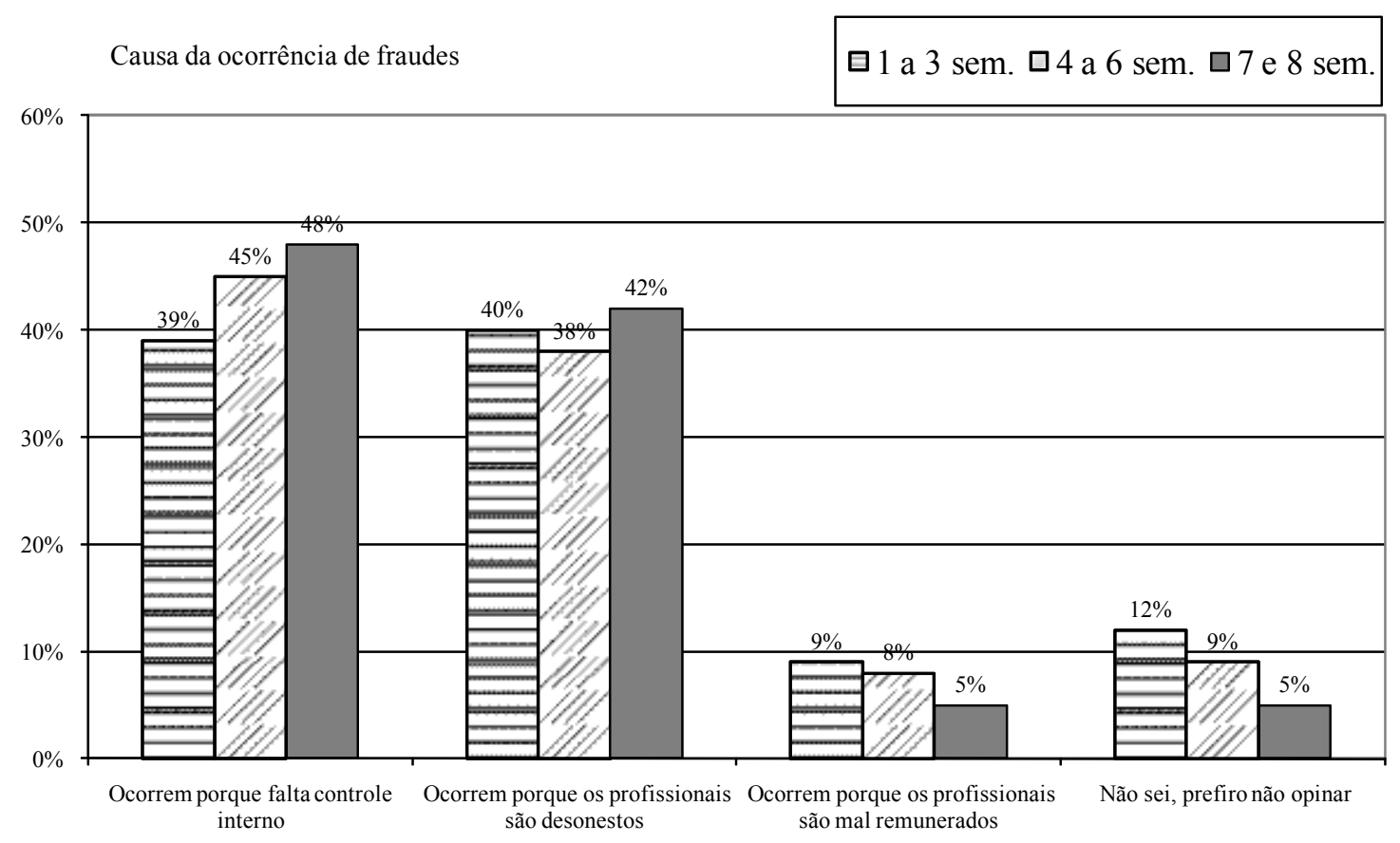

Gráfico 5 - Causas das ocorrências de fraudes

Fonte: Elaborado pelos autores

A parcela de cada grupo que compreende que as infrações ocorrem porque os profissionais são desonestos, manifesta, na escolha desta alternativa, certa descrença na índole moral de membros da categoria. Acredita-se que deveria ocorrer o contrário, pois, segundo Fortes (2005), a conduta dos profissionais precisaria ser sempre pautada pela honestidade e dignidade, de forma que essas qualidades se transformassem em diferencial e lhes conferissem autoridade moral.

\subsubsection{Quando no exercício profissional constato que um colega não esta sendo ético}

Observa-se que $62 \%, 71 \%$ e $70 \%$ dos alunos de cada grupo da amostra dizem que alertariam o colega sobre as consequências de agir de forma não ética, isto é, antes de tomar qualquer outra atitude procuraria conversar, demonstrando, assim, atitude de coleguismo (Gráfico 6). Para 3\%, 2\% e 1\% da amostra de cada grupo, o melhor é ficar quieto para não prejudicar ninguém, enquanto que, para $27 \%, 18 \%$ e $22 \%$, o mais conveniente seria comunicar as pessoas responsáveis. Nota-se que $8 \%, 9 \%$ e $6 \%$ de cada grupo da amostra preferiram não opinar, entendendo-se que estes alunos não sabem como agiriam em situação semelhante. 


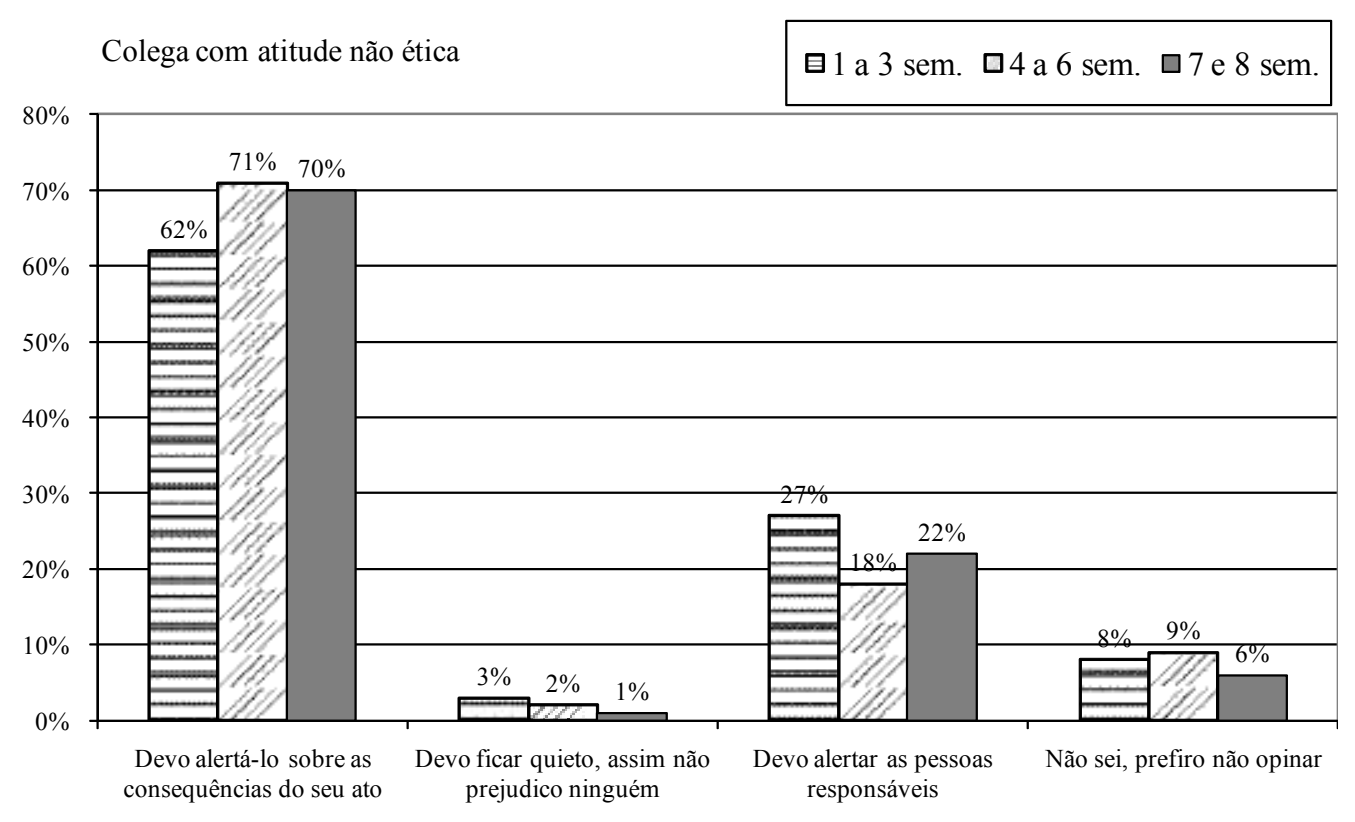

Gráfico 6 - Se um colega não está sendo ético

Fonte: Elaborado pelos autores

Convém mencionar que o CEPC, no Capítulo IV, artigos $9^{\circ}$ e $10^{\circ}$ (CFC, 1996), enumera alguns deveres do profissional da Contabilidade em relação aos colegas de classe. Ressalta-se que os contabilistas devem agir com solidariedade, respeito e apreço. Isso não quer dizer que devam ser coniventes com os erros ou infringir normas em nome do coleguismo. Deste modo, a atitude de alertar um colega que está incorrendo em ato ilícito constitui-se uma obrigação para o profissional contábil.

\subsubsection{Quando meu superior me pede para fazer algo que não é correto}

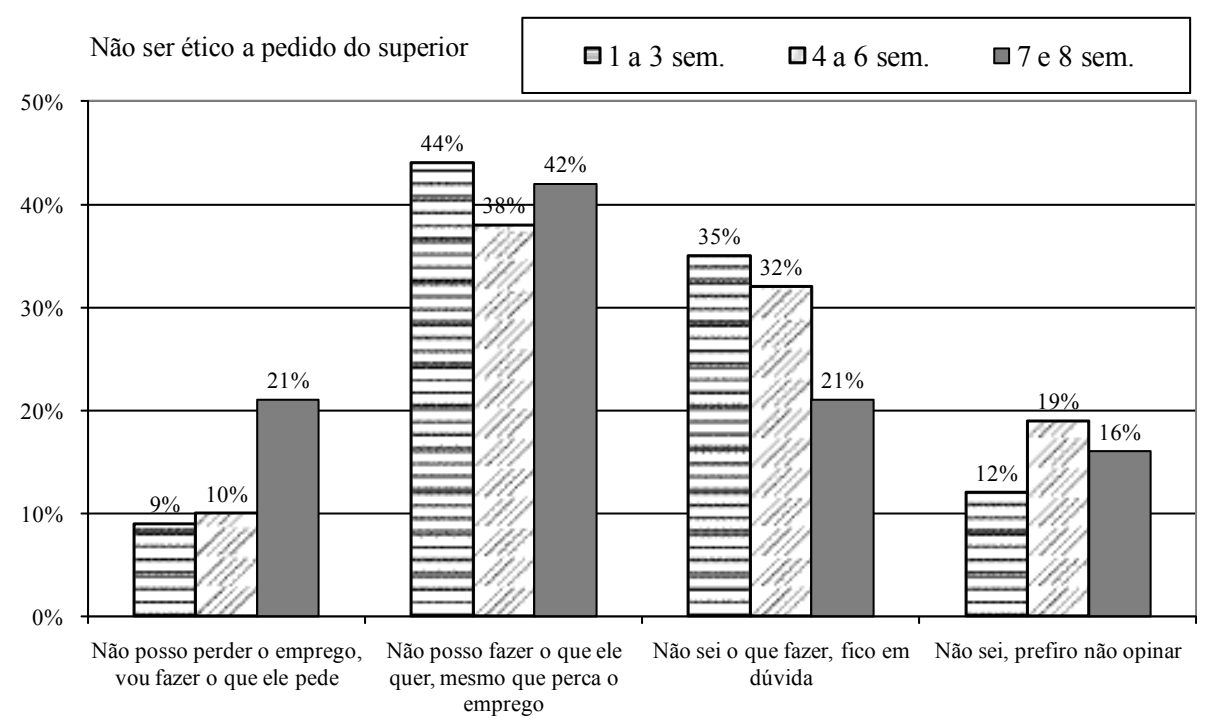

Gráfico 7: Se o superior pede para fazer algo que não é correto

Fonte: Elaborado pelos autores 
Verifica-se grande diversidade de opinião para esta questão (Gráfico 7). Destaca-se que, para $9 \%, 10 \%$ e $21 \%$ dos grupos da amostra, é melhor fazer o que o superior pede; para não perder o emprego, mesmo que não seja correto, enquanto que $44 \%, 38 \%$ e $42 \%$ afirmam que não fariam o que o superior pede, ainda que perdessem o emprego.

Chamam atenção os percentuais 35\%, 32\% e 21\%. Esses alunos dizem que ficariam em dúvida entre fazer, ou não, o que lhes é solicitado. Pode-se dizer que esta parcela da amostra não tem uma opinião formada e podem, por isso, estar mais propensos e suscetíveis à execução de práticas ilegais, no intuito de manter o atual emprego. É preocupante que parte significativa dos futuros profissionais da Contabilidade fiquem em dúvida quanto à atitude correta a ser adotada em circunstância semelhante.

O CEPC, no art. $3^{\circ}$ (CFC, 1996), cita ações e procedimentos que são vedados ao contabilista. O inciso VIII proíbe o profissional a "concorrer para a realização de ato contrário à legislação ou destinado a fraudá-la ou praticar, no exercício da profissão ato definido como crime ou contravenção". O inciso XXI veta ao contabilista "renunciar à liberdade profissional, devendo evitar quaisquer restrições ou imposições que possam prejudicar a eficácia e correção de seu trabalho". Entende-se que o profissional não deve agir de forma contrária à lei, mesmo que lhe seja solicitado por superior ou empregador.

\subsubsection{Quando constato que um cliente ou fornecedor não está agindo de forma ética}

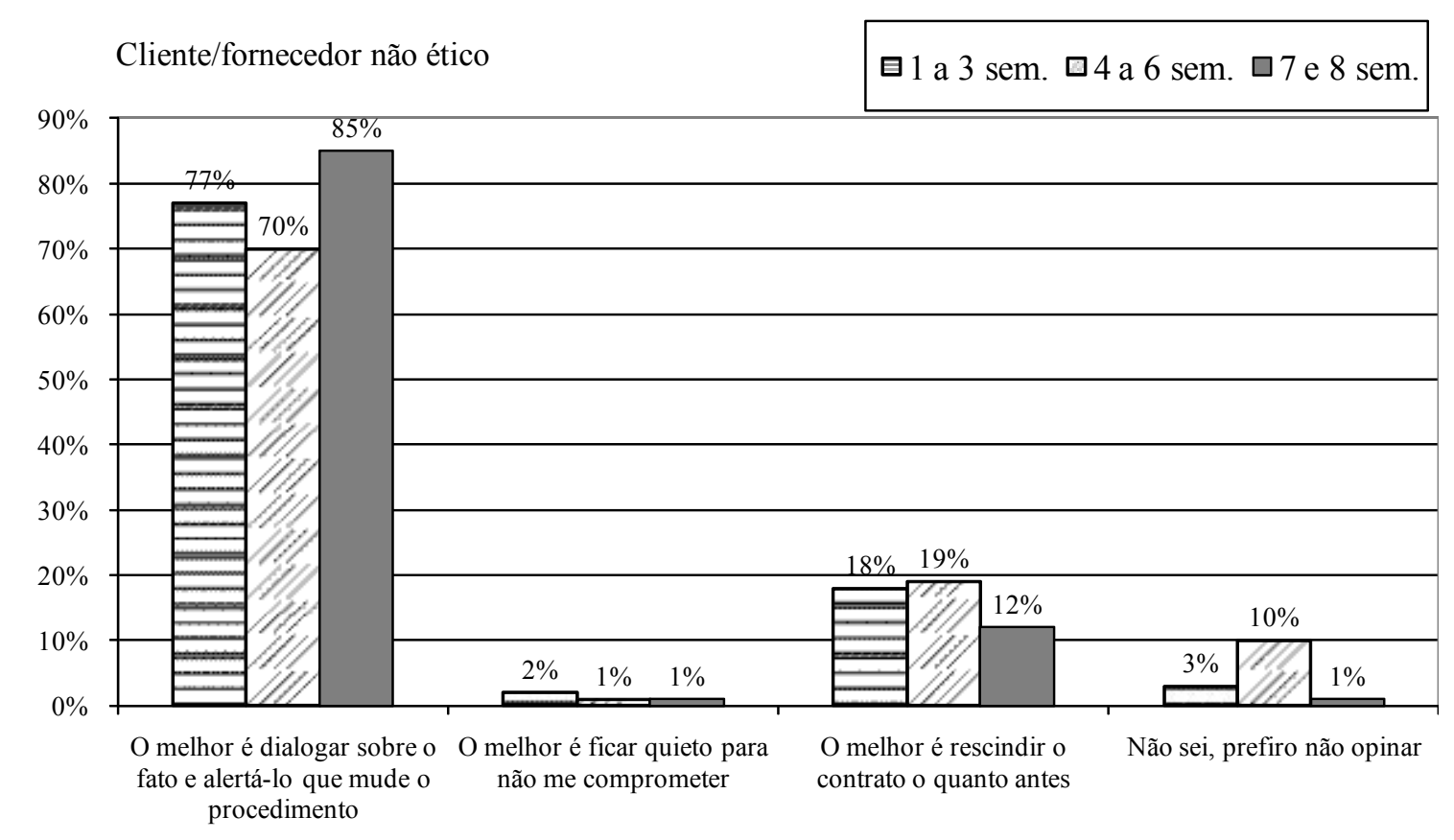

Gráfico 8 - Se um cliente ou fornecedor não está sendo ético Fonte: Elaborado pelos autores 
Observa-se que a alternativa com maiores percentuais $77 \%, 70 \%$ e $85 \%$ é a que afirma que o melhor é dialogar com esses fornecedores ou clientes, buscando apresentar razões para que o procedimento adotado seja substituído por outro mais adequado (Gráfico 8).

A alternativa que menciona como melhor atitude ficar quieto para evitar comprometimento apresentou os percentuais de $2 \%, 1 \%$ e $1 \%$, enquanto que a alternativa que cita que o melhor a se fazer é rescindir o contrato o quanto antes obteve $18 \%, 19 \%$ e $12 \%$ das respostas. Observa-se que 3\%,10\% e 1\% de alunos preferiram não opinar. Destaca-se que apenas $1 \%$ dos alunos em final de curso absteve-se de manifestar seu posicionamento para esta questão.

O posicionamento predominante dos grupos está em harmonia com o pensamento de Fortes (2005) de que é recomendável que o profissional contábil oriente seu cliente sobre as consequências de praticar ato ilícito e que não ceda, em hipótese alguma, às pressões para que ele mesmo cometa qualquer tipo de ato indevido. Ele entende que é dever do contabilista orientar seu cliente sobre a obrigatoriedade de certos procedimentos em âmbito contábil ou fiscal, ou seja, é obrigação do profissional contábil orientar e advertir seu cliente ou fornecedor para que ajam em conformidade com a lei.

\subsection{Análise do perfil teórico moral}

\subsubsection{Quanto ao conceito de ética}

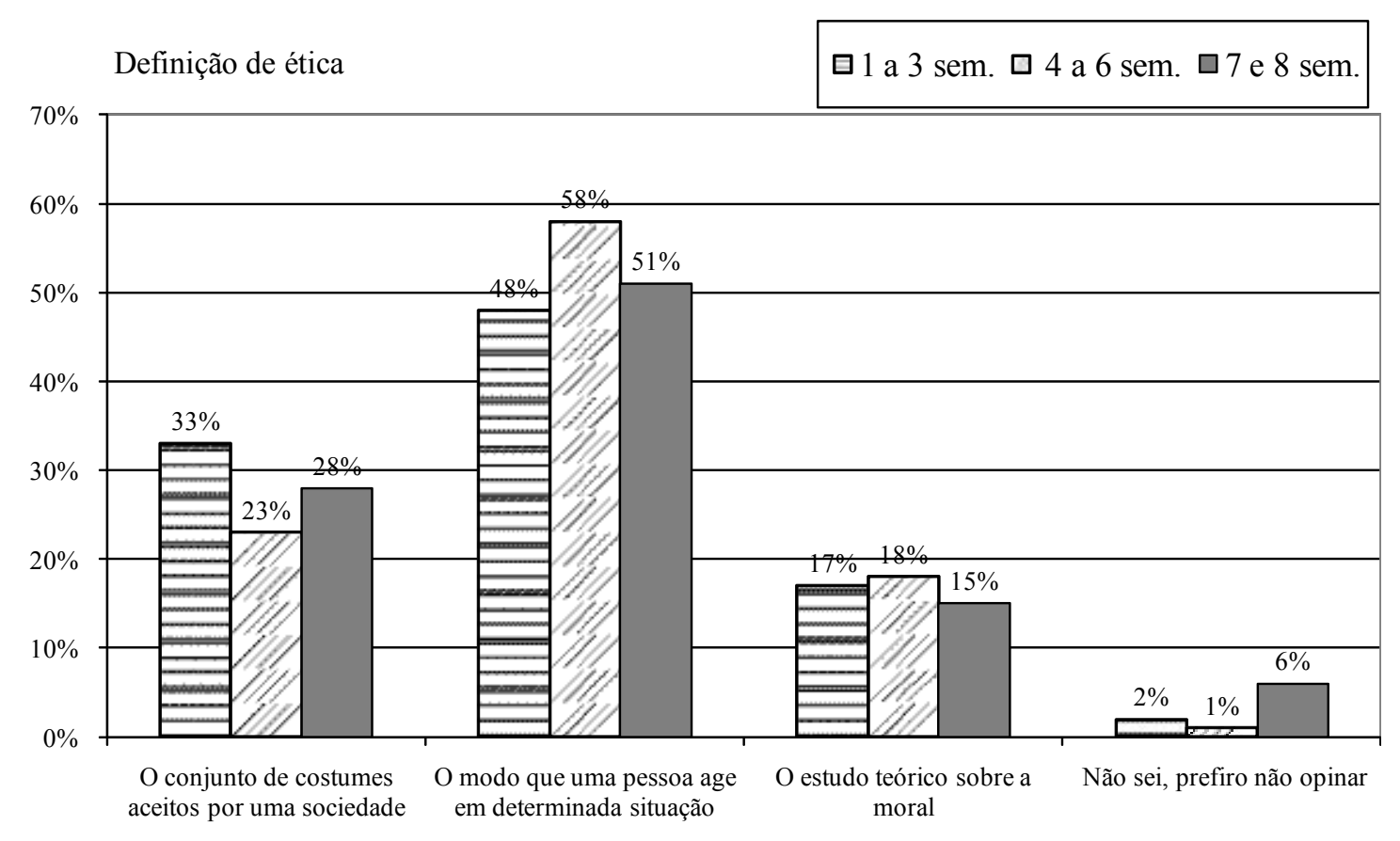

Gráfico 9 - Definição de ética

Fonte: Elaborado pelos autores 
Observa-se que a alternativa que diz que a moral é o conjunto de costumes aceitos por uma sociedade apresenta, respectivamente, 33\%, 23\% e 28\% das respostas dos grupos (Gráfico 9). Nota-se que a alternativa com percentuais mais elevados (48\%, $58 \%$ e $51 \%$ ) é a que define ética como o modo que uma pessoa age em determinada situação. Para $17 \%, 18 \%$ e $15 \%$ dos alunos, a ética é o estudo teórico sobre a moral.

Tradicionalmente tem-se estabelecido que a ética é o estudo teórico sobre a moral. Vasquez entende que a "ética não é a moral e, portanto, não pode ser reduzida a um conjunto de normas e prescrições; sua missão é explicar a moral efetiva" (VASQUEZ, 1989, p. 13). Bittar afirma que a ética "constitui-se num saber especulativo acerca da moral" (BITTAR, 2007 p. 11). Lisboa compreende que a ética "conduz à ideia da universalidade moral, ou ainda, à forma ideal universal do comportamento humano" (LISBOA, 1997, p. 24). Entende-se, portanto, que existe diferença conceitual entre moral e ética. Pode-se visualizar pelo gráfico, que somente uma pequena parcela da população conseguiu definir ética segundo este entendimento.

\subsubsection{Quanto à importância da ética}

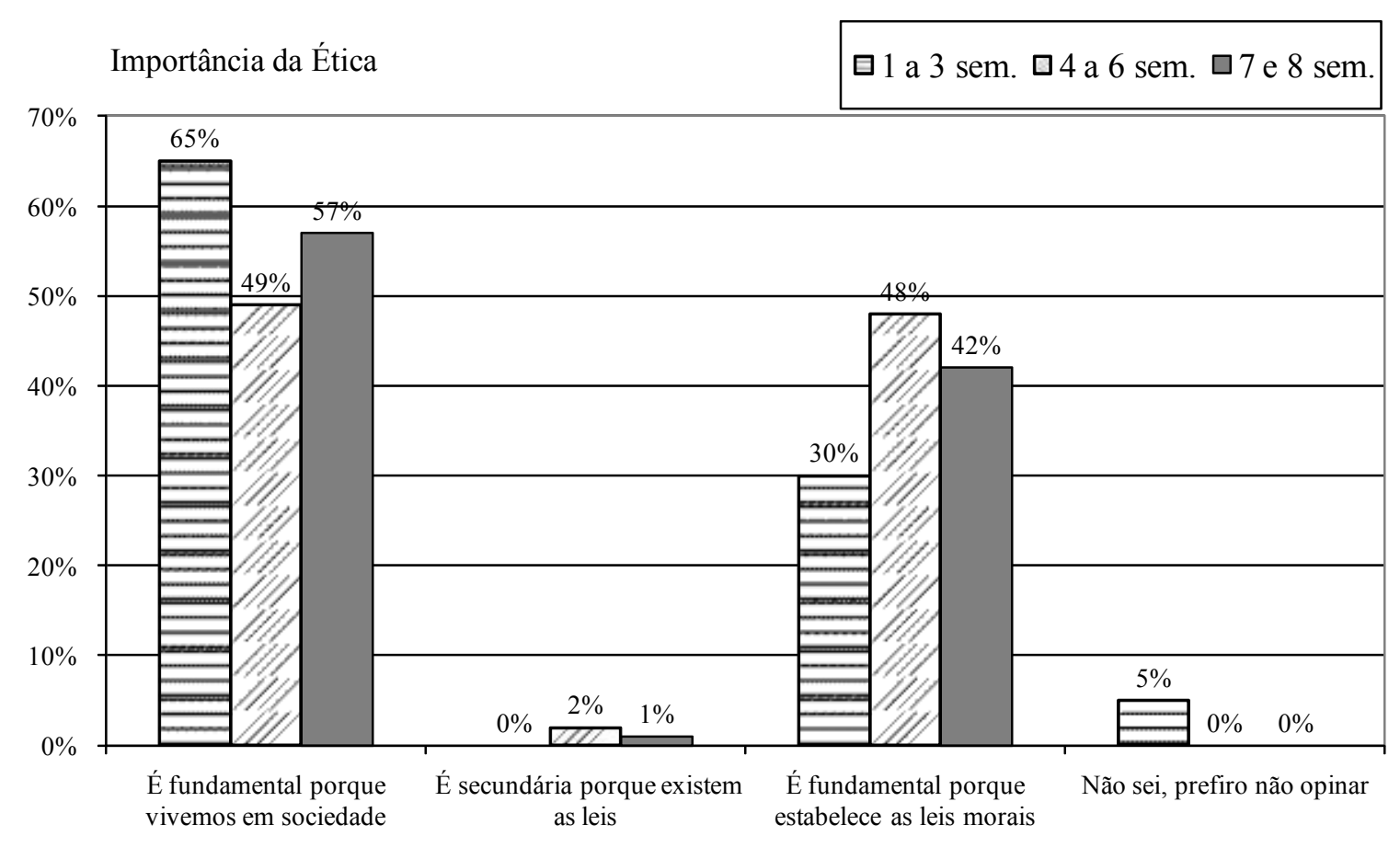

Gráfico 10 - Importância da ética

Fonte: Elaborado pelos autores

Constata-se que o entendimento predominante nos grupos (65\%, 49\% e $57 \%$ ) é o que atribui importância à ética pelo fato de se viver em sociedade (Gráfico 10). Este posicionamento vai ao encontro do pensamento de Fortes (2005) de que as obrigações no campo ético são decorrentes da participação nos grupos sociais, isto é, são consequências da vida em sociedade. 
A alternativa que considera a ética como secundária porque existem as leis obteve percentuais irrelevantes $(0 \%, 2 \%$ e $1 \%)$. Vasquez (1989) diz que a moral e o direito têm, em comum, características, como o fato de ambos regulamentarem as relações humanas por meio de normas ou terem a forma de imperativos. Entretanto, as normas morais são observadas porque existem adesão e convicção (interiorização), enquanto que as normas jurídicas não exigem convicção ou adesão, pois mesmo que não se esteja convencido de que a norma ou lei é justa, ela deve ser observada (exteriorização).

Observa-se que parcela significativa (30\%, 48\% e 42\%) entende que a ética é importante porque estabelece as leis morais. Este posicionamento diverge do pensamento de Bittar (2007), segundo o qual a ética não é em si mesma um código ou um conjunto de regras, é antes de tudo um saber especulativo que busca compreender fatos e comportamentos.

\subsubsection{Quanto à formação acadêmica do profissional da Contabilidade em seu aspecto ético}

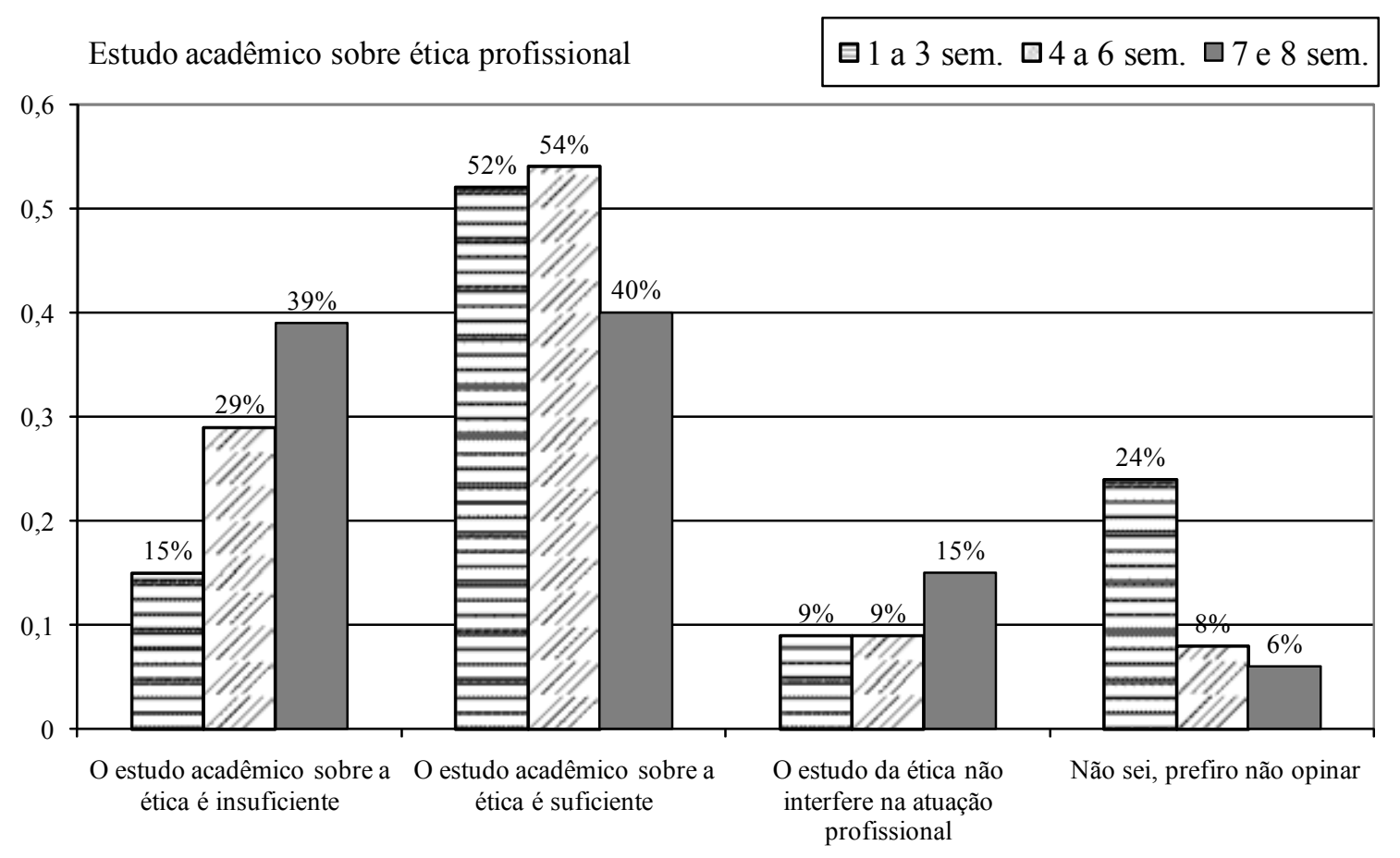

Gráfico 11 - Estudo acadêmico sobre ética profissional Fonte: Elaborado pelos autores

Constata-se que $15 \%, 29 \%$ e $39 \%$ dos alunos dos grupos da amostra consideram insuficiente o estudo acadêmico sobre ética (Gráfico 11). Chama atenção que $39 \%$ dos alunos que estão concluindo o curso tenham esta percepção.

Conforme pode ser observado no gráfico, no entanto, para 52\%, 54\% e 40\%, a formação acadêmica sobre assuntos éticos é considerada suficiente para se inteirarem da complexidade dessas questões em âmbito profissional. Essa postura, de certa forma, contradiz 
a resposta ao item 4.3 (a) (Gráfico 9), que mostra que os graduandos têm um conhecimento imperfeito sobre o conceito de ética.

Verifica-se que, para 9\%, 9\% e 15\% dos alunos de cada grupo, a formação acadêmica em seu aspecto ético não interfere na atuação profissional. Pode-se dizer que esses alunos entendem que, mesmo que não se estude ética geral e profissional, é possível se ter uma vivência profissional reta e idônea. Porém, segundo Bittar (2007), não é possível dissociar a ética do processo educacional, pois a educação é vista como um processo de aperfeiçoamento intelectual, físico e moral.

\subsubsection{Quanto ao Código de Ética do Profissional da Contabilidade}

Observa-se que parcela irrelevante (2\%, $2 \%$ e 1\%) considera o código de ética profissional da categoria desnecessário (Gráfico 12). Destaca-se que, para $83 \%, 73 \%$ e $61 \%$ dos alunos da amostra, o CEPC é necessário, mas nunca o leram. Nota-se que este percentual diminui conforme aumenta o semestre, isto é, o número de alunos em final de curso que não conhecem o CEPC é menor que nos semestres iniciais, apresentando variação de $-22 \%$. No entanto o percentual do grupo 3 (61\%) ainda é bastante elevado e preocupante, pois são profissionais que já estão estudando Contabilidade há um bom tempo e desconhecem este importante documento. Considere-se, adicionalmente, que boa parte dos alunos do curso já atua profissionalmente na área.

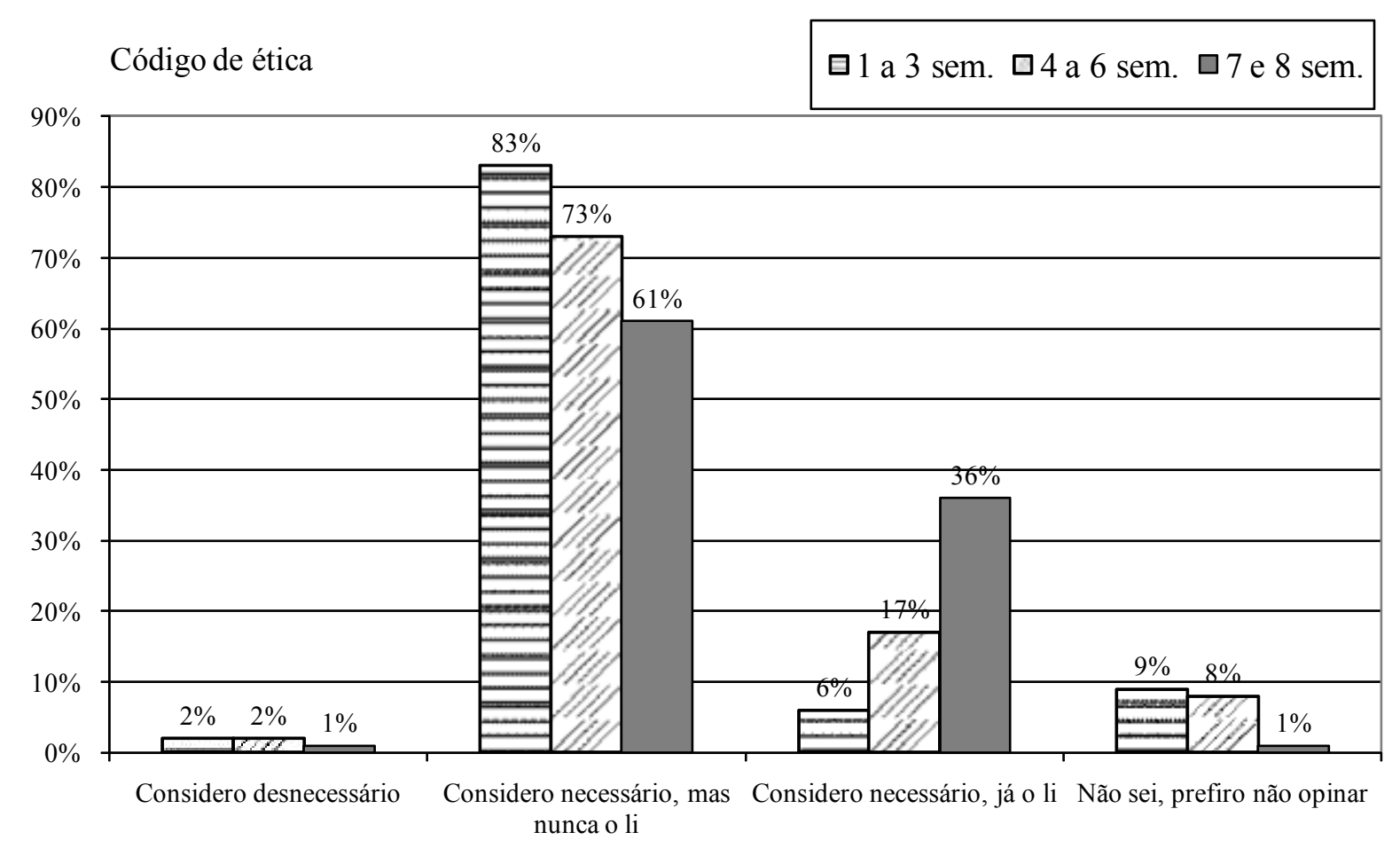

Gráfico 12 - Código de Ética do Profissional do Contabilista

Fonte: Elaborado pelos autores 
Observa-se que apenas $6 \%, 17 \%$ e $36 \%$ dos alunos leram o código de ética profissional, ou seja, apesar de muitos o considerarem necessário, apenas uma minoria inteirou-se do assunto. Observa-se, pelo gráfico, que, conforme avança o semestre, aumenta também o percentual de alunos que conhecem o CEPC. Porém, mesmo assim, os dados revelam mais de $70 \%$ dos alunos não leram o CEPC. Segundo o currículo do curso de Ciências Contábeis da IES, a disciplina relativa à ética situa-se no quinto semestre; assim, é muito provável que os alunos de final de curso (sétimo e oitavo semestres) já a tenham cursado. Isso reforça a preocupação com a baixa parcela de alunos que declaram ter lido o CEPC.

Convém citar a pesquisa realizada por Alves (2005) acerca da adesão do contabilista ao seu código de ética; concluiu que nem todos os profissionais que consideravam o CEPC importante como guia de conduta estavam dispostos a segui-lo. Pode-se dizer que não basta considerar o CEPC necessário e importante, é imprescindível que ele seja conhecido e observado.

\subsubsection{Sobre as punições impostas aos profissionais da Contabilidade que cometem infrações}

Como pode ser observado no Gráfico 13, 5\%, 9\% e 27\% dos alunos de cada grupo sabem quais são as punições. Este percentual é maior entre os alunos que estão nos semestres finais. Constata-se que 79\%, 79\% e 63\% sabem que existem as punições, porém não sabem quais são. Nota-se ainda que $2 \%, 4 \%$ e $6 \%$ dos alunos de cada grupo sabem que existem punições, mas não se preocupam com elas, enquanto que 15\%, $8 \%$ e $4 \%$ dos alunos preferiram não se manifestar.

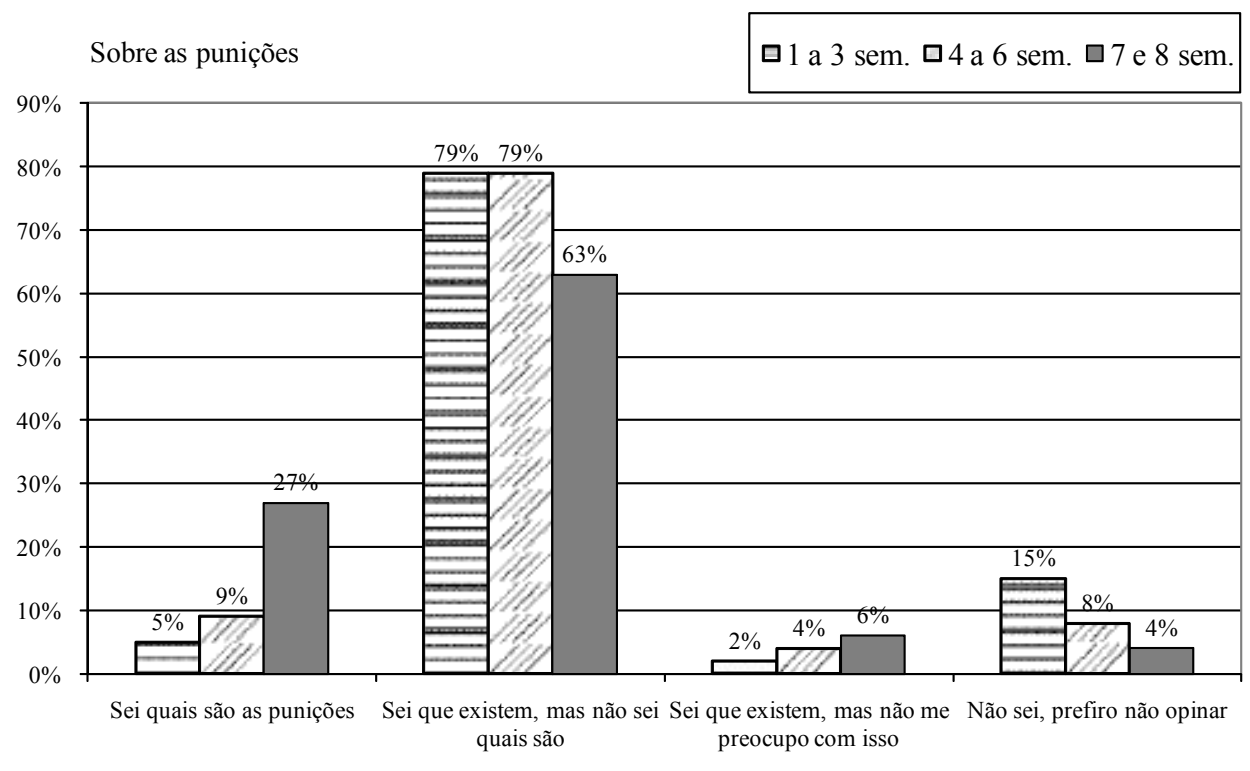

Gráfico 13 - Punições impostas aos profissionais que cometem infrações

Fonte: Elaborado pelos autores 
Pode-se dizer que os percentuais obtidos apenas confirmam o que já foi verificado no Gráfico 12, isto é, que os alunos de graduação do curso de Ciências Contábeis da amostra analisada não conhecem o CEPC, pois se o tivessem lido saberiam quais são as penalidades aplicadas aos profissionais que cometem infrações.

Fortes (2005) menciona que, na aplicação de sanções éticas (advertência reservada, censura reservada, censura pública), o código de ética prevê a possibilidade de circunstâncias atenuantes, como, por exemplo, falta cometida em defesa de prerrogativa profissional, ausência de punição anterior e a relevância de serviços prestados à Contabilidade.

O CEPC traz, no Capítulo V, art. $12^{\circ}$ (CFC, 1996), as penalidades e as circunstâncias atenuantes. Neste mesmo Capítulo, no art. $13^{\circ}$, menciona-se que o julgamento das questões éticas é incumbência dos Conselhos Regionais de Contabilidade (CRC), que funcionam como Tribunais Regionais de Ética e Disciplina.

\subsubsection{Quanto à atuação ética profissional do contabilista}

Pode-se observar que, para 24\%, 30\% e 27\% dos alunos de cada grupo (Gráfico 14), o agir ético do profissional é influenciado pela família, isto é, estimam que ela desempenha importante papel na formação do caráter do profissional. Este posicionamento converge com o entendimento de Vasquez (1989) de que as ideias morais e os modelos de comportamento moral são adquiridos aos poucos pelo indivíduo, pois é um processo que se inicia na infância, através da influência dos pais e de outros fatores, como escola e amigos.

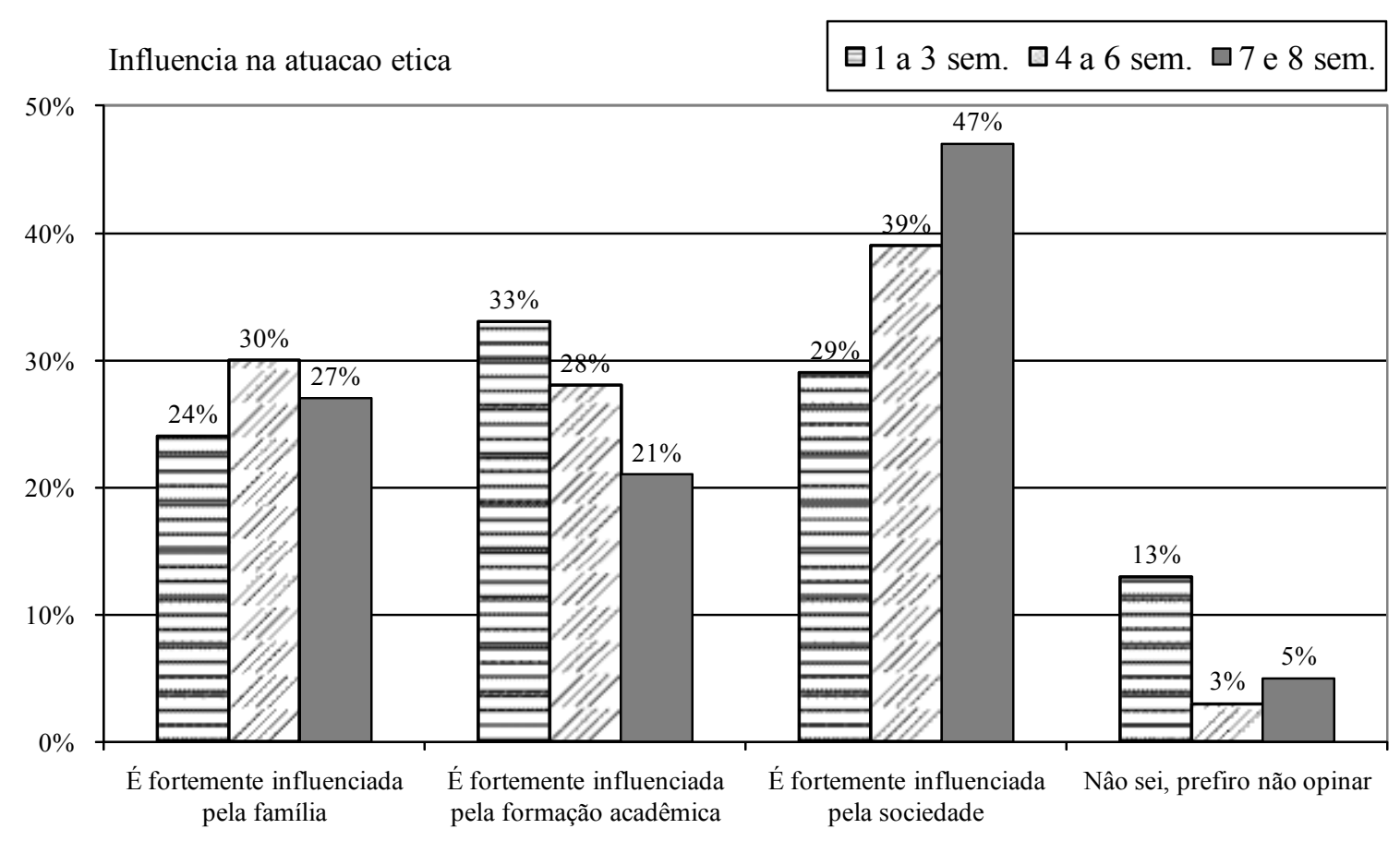

Gráfico 14- Fatores que influenciam na atuação ética profissional

Fonte: Elaborado pelos autores 
Observa-se que $33 \%, 28 \%$ e $21 \%$ dos alunos compreendem que a atuação ética profissional é fortemente influenciada pela formação acadêmica. Bittar (2007), no entanto, expondo sobre a ética e o ensino superior constata que a formação primária e secundária perdeu qualidade, pois falta aos alunos consciência histórica, antropológica, filosófica e, sobretudo, questiona se não está faltando também consciência ética. Menciona ainda que essas lacunas educacionais repercutem no ensino superior.

Para 29\%, 39\% e 47\% dos alunos da amostra, a atuação ética profissional é fortemente influenciada pela sociedade. Este posicionamento encontra respaldo no pensamento de Fortes (2005), segundo o qual o indivíduo está sujeito à influência do meio social em que se encontra.

\section{CONSIDERAÇÕES FINAIS E RECOMENDAÇÕES}

Com esta pesquisa, buscou-se estudar o perfil prático moral e teórico moral dos futuros profissionais da Contabilidade graduados pela IES analisada. Neste intuito foi aplicado um questionário para 232 alunos do curso de Ciências Contábeis, distribuídos entre os diversos semestres.

A análise das evidências apontou como características predominantes do perfil prático moral e teórico moral dos alunos da amostra os seguintes itens:

a) Entendem que os profissionais da Contabilidade que cometem infrações estão visando vantagens.

b) Compreendem que as fraudes contábeis ocorrem porque falta controle interno.

c) Ponderam que o melhor a se fazer quando se constata que um colega não esta sendo ético é alertá-lo sobre as consequências do seu ato.

d) Dizem que, quando o superior pede para fazer algo que não é ético, o melhor é não fazer o que ele solicita, mesmo que se perca o emprego.

e) Julgam que se um cliente ou fornecedor não estiver agindo de forma ética o melhor é solicitar que mude o procedimento adotado.

h) Definem ética como o modo que uma pessoa age em determinada situação.

i) Compreendem que a ética é fundamental porque se vive em sociedade.

j) Entendem que o estudo acadêmico sobre ética é suficiente.

I) Consideram o CEPC necessário, mas nunca o leram.

n) Sabem que existem punições que são aplicadas aos profissionais que cometem infrações, mas não sabem quais são elas.

o) Entendem que a atuação ética do profissional é fortemente influenciada pela sociedade. Esses elementos dizem respeito às alternativas que obtiveram percentuais mais elevados, ou seja, ficaram em $1^{\circ}$ lugar na opção dos alunos. 


\section{repec}

Pode-se dizer, de acordo com o perfil predominante, que os graduandos demonstraram, em teoria, ter julgamento condizente com o esperado para futuros profissionais da Contabilidade, principalmente no que se referem às atitudes em relação a colegas, clientes, fornecedores e superiores. Apresentaram, na prática, lacunas na sua formação, no que diz respeito ao não conhecimento do CEPC e à ausência de base conceitual suficiente para que pudessem definir ética segundo a concepção tradicional. Do ponto de vista da moral kantiana, portanto, há certa discordância, na medida em que os alunos, embora demonstrem ter conhecimento teórico mínimo de ética, em termos práticos, tendem a agir segundo suas inclinações, o que fere o princípio estabelecido pelo imperativo categórico (KANT, 1938).

Pode-se inferir que, em âmbito geral, a sociedade desempenha importante papel na formação ética dos futuros profissionais. A formação acadêmica também é relevante neste processo de formação, seja no aspecto prático ou no aspecto teórico. Entende-se que a sociedade e a instituição de ensino devem incentivá-los a exercer com honestidade a profissão. Cabe à universidade apresentar estimulá-los a ter uma conduta correta, fazê-los conhecer o CEPC, ajudá-los a obter clareza conceitual para que, no exercício profissional, possam se valer de uma adequada formação seja no âmbito técnico, humanístico, antropológico, filosófico e sociológico.

Neumann (2007), abordando as percepções dos alunos e dos professores da IES da amostra analisada, constata que a própria instituição reconhece que existe pressão para que se faça opção por uma educação que priorize as habilidades de mercado. No entanto, a IES entende que a educação vai muito além e contempla a pessoa como um todo, inclusive em seu aspecto moral. Segundo pesquisa realizada por Pires (2008), o mercado de trabalho exige cada vez mais do profissional uma gama infinita de qualificações, não sendo mais suficiente apenas possuir os conhecimentos que tradicionalmente estavam relacionados com Contabilidade - é necessário muito mais do que isso. É preciso, segundo a autora, que o profissional esteja preparado para adquirir e desenvolver capacidades ligadas ao trabalho em equipe e a capacidade de liderança, além de possuir conhecimento sobre tecnologia da informação, administração, economia, recursos humanos e outras áreas afins. Pode-se dizer que todas essas capacitações exigem e subtendem um profissional que possua conduta moral irrepreensível.

Esta pesquisa constatou a existência de tendência favorável à execução da profissão contábil de forma idônea, honesta e ética. Pode ser que esta predisposição não seja mantida pela totalidade dos contabilistas no decorrer do exercício profissional, isto porque os dados apresentados pelo CRCRS demonstram a ocorrência de muitas infrações e isso significa que deve existir algum fator que induz o profissional a agir em dissonância com as prerrogativas legais da profissão (CRCRS, 2010). Recomenda-se, portanto, que seja realizado um estudo semelhante com profissionais que já estão formados e atuando na área da Contabilidade há mais tempo. 
Outro estudo interessante poderia ser feito se fosse disponibilizado o acesso aos autos dos processos éticos que correm no CRC do Rio Grande do Sul. Seria possível estabelecer, por exemplo, a relação entre infração cometida e defesa apresentada ou entre as causas das infrações e as consequências desses atos, entre outras. Embora haja restrições para o acesso aos processos, certos cuidados no manuseio das informações poderiam ser tomados, de forma a preservar a confidencialidade e, ao mesmo tempo, permitir o estudo dessa temática.

\section{REFERÊNCIAS}

ALVES, Francisco José dos Santos. Adesão do Contabilista ao Código de Ética da sua profissão: um estudo empírico sobre percepções. 2005. Tese (Doutorado em Controladoria e Contabilidade). Faculdade de Economia, Administração e Contabilidade. Universidade de São Paulo, SP, 2005.

ARANHA, Maria Lucia de Arruda; MARTINS, Maria Helena Pires. Filosofando. 2. ed. São Paulo: Moderna, 1993.

BITTAR, Eduardo C.B. Curso de Ética Jurídica - Ética Geral e Profissional. 5. ed. São Paulo: Saraiva, 2007.

BORGES, Erivan; MEDEIROS, Carlos. Comprometimento e Ética Profissional: um estudo de suas relações junto aos contabilistas. Revista Contabilidade \& Finanças. São Paulo: n.44, p. 60-71. mai./ago. 2007.

CAMARGO, Marculino. Fundamentos de Ética Geral e Profissional. Petrópolis: Vozes, 1999.

CONSELHO REGIONAL DE CONTABILIDADE DO RIO GRANDE DO SUL (CRC). Relatório de Fiscalização - 2009 . Disponível em: <www.crcrs.org.br/fiscalizacao/relatorio_2009>. Acesso em: 23 mai. 2010.

COSTA, Adilson. Competências e habilidades: Um estudo dos Egressos do Curso de Ciências Contábeis no Estado de Santa Catarina. Dissertação (Mestrado). Blumenau, 2007. Disponível em: <http://proxy.furb.br/tede/tde_busca/arquivo. php?codArquivo=530>. Acesso em: 19 out. 2009.

FORTES, José Carlos. Manual do Contabilista. São Paulo: Saraiva, 2005.

GIL, Antonio Carlos. Como elaborar projetos de pesquisa. 4. ed. São Paulo: Atlas, 2002. 
HARADA, Elaine. Etapas da pesquisa científica. 2003. Disponível em: <www.dcc.ufam. edu.br/ elaine/mccc_06.ppt>. Acesso em: 17 out. 2009.

HENDRIKSEN. Eldon S; VAN BREDA, Michael F. Teoria da Contabilidade. 5. ed. São Paulo: Atlas, 1999.

INSTITUTO NACIONAL DE PESQUISAS E ESTUDOS EDUCACIONAIS. Cadastro das Instituições de ensino superior - INEP. Disponível em: <http://www.educacaosuperior. inep.gov.br/funcional/busca_instituicao.stm>. Acesso em: 14 out. 2009.

INSTITUTO NACIONAL DE PESQUISAS E ESTUDOS EDUCACIONAIS. Cadastro das Instituições de ensino superior - INEP. Disponível em: <http://www.educacaosuperior. inep.gov.br/funcional/busca_curso.stm>. Acesso em: 14 out. 2009.

INSTITUTO NACIONAL DE PESQUISAS E ESTUDOS EDUCACIONAIS. Censo da Educação Superior - INEP. Disponível em: <http://www.inep.gov.br/imprensa/noticias/censo/ superior/news09_01.htm>. Acesso em: 14 out. 2009.

IUDÍCIBUS, Sérgio de et al. Manual de Contabilidade das sociedades por ações. 6. ed. São Paulo: Atlas, 2006.

IUDÍCIBUS, Sérgio de; MARION, Jose Carlos. Introdução à teoria da Contabilidade para o nível de graduação. 3. ed. São Paulo: Atlas, 2002.

KANT, Immanuel. The Fundamental Principles of the Metaphisics of Ethics. New York: D. Appleton-Century Co., 1938. Fundamentação da Metafísica dos Costumes in: PENSADORES. São Paulo: Abril Cultural, 1980, 2 v.

LAKATOS, Eva Maria; MARCONI, Marina de Andrade. Fundamentos de Metodologia Cientifica. 6. ed. São Paulo: Atlas, 2008.

LISBOA, Lazaro Plácido et al. Ética Geral e Profissional em Contabilidade. 2. ed. São Paulo: Atlas, 1997.

MOTTA, Nair de Souza. Ética e Vida Profissional. Rio de Janeiro: Âmbito Cultural, 1984.

NALINI, Jose Renato. Ética Geral e Profissional. 2. ed. São Paulo: Editora Revista dos Tribunais, 1999. 
NEUMANN, Laurício. Sentido das disciplinas de formação humanística e social de orientação cristã da UNISINOS conforme percepção de alunos e professores. Tese (Doutorado) - Universidade do Vale do Rio dos Sinos. São Leopoldo, 2007. Disponível em: <http:// bdtd.UNISINOS.br/tde_busca/arquivo.php?codArquivo=433>. Acesso em: 18 out. 2009.

PELEIAS et al. Evolução do ensino da Contabilidade no Brasil: uma análise histórica. Revista Contabilidade \& Finanças. São Paulo, Edição 30 Anos de Doutorado, p. 19-31, jun/2007.

PIRES, Charline Barbosa. A formação e a demanda do mercado de trabalho do contador na região metropolitana de Porto Alegre - RS. Dissertação (Mestrado) - Universidade do Vale do Rio dos Sinos. São Leopoldo, 2008. Disponível em: <http://bdtd.UNISINOS. br/tde_busca/arquivo.php?codArquivo=705>. Acesso em: 17 out. 2009.

RESOLUÇÃO CFC N. 803/96. Aprova o código de ética do profissional do contabilista. Disponível em: <http://www.crcsp.org.br/portal_novo/legislacao_contabil/resolucoes/ Res803.htm>. Acesso em 28 set. 2009.

RESOLUÇÃO CFC N. 949/02. Aprova o regulamento de procedimentos processuais dos conselhos de Contabilidade, que dispõe sobre os processos adminstrativos de fiscalização, e dá outras providências. Disponível em: <http://www.crcsp.org.br/portal_novo/legislacao_contabil/resolucoes/Res949.htm>. Acesso em 28 set. 2009.

RESOLUÇÃO CFC N. 960/03. Regulamento geral dos conselhos de Contabilidade. Disponível em: <http://www.cfc.org.br/sisweb/sre/docs/RES_960.doc>. Acesso em 28 set. 2009 SÁ, Antonio Lopes de. Fraudes Contábeis. Rio de Janeiro: Tecnoprint, 1982.

História geral e das doutrinas da Contabilidade. São Paulo: Atlas, 1997. Ética profissional. 3. ed. São Paulo: Atlas, 2000.

Fundamentos da Contabilidade Geral. 2. ed. Curitiba: Juruá, 2008.

SCHMIDT, Paulo. História do Pensamento Contábil. Porto Alegre: Bookman, 2000.

SILVA, Antonio Carlos Ribeiro da. Metodologia da pesquisa aplicada à Contabilidade: orientações de estudos, projetos, artigos, relatórios, monografias, dissertações, teses. 2. ed. São Paulo: Atlas, 2008.

VÁSQUEZ, Adolfo Sánchez. Ética. 11. ed. Rio de Janeiro: Civilização Brasileira. 1987. 